\title{
Provenance of Permian eolian and related strata in the North American midcontinent: Tectonic and climatic controls on sediment dispersal in western tropical Pangea
}

\author{
M.J. Soreghan \\ M.M. Swift \\ G.S. Soreghan \\ School of Geology and Geophysics, University of Oklahoma, Norman, Oklahoma 73019, USA
}

\begin{abstract}
The Permian marks a time of substantial climatic and tectonic changes in the late Paleozoic. Gondwanan glaciation collapsed after its earliest Permian acme, aridification affected the equatorial region, and monsoonal conditions commenced and intensified. In western equatorial Pangea, deformation associated with the Ancestral Rocky Mountains continued, while the asynchronous collision between Laurentia and Gondwana produced the Central Pangean Mountains, including the AppalachianOuachita-Marathon orogens bordering eastern and southern Laurentia, completing the final stages of Pangean assembly. Permian red beds of the southern midcontinent archive an especially rich record of the Permian of western equatorial Pangea. Depositional patterns and detrital-zircon provenance from Permian strata in Kansas and Oklahoma preserve tectonic and climatic histories in this archive. Although these strata have long been assumed to record marginal-marine (e.g., deltaic, tidal) and fluvial deposition, recent and ongoing detailed facies analyses indicate a predominance of eolian-transported siliciclastic material ultimately trapped in systems that ranged from eolian (loess and eolian sand) to ephemerally wet (e.g., mud flat, wadi) in a vast sink for mud to fine-grained sand. Analyses of U-Pb isotopes of zircons for 22 samples from Lower to Upper Permian strata indicate a significant shift in provenance reflected in a reduction of Yavapai-Mazatzal and Neoproterozoic sources and increases in Grenvillian and Paleozoic sources. Lower Permian (Cisuralian) strata exhibit nearly subequal proportions of Grenvillian, Neoproterozoic, and YavapaiMazatzal grains, whereas primarily Grenvillian and secondarily early Paleozoic grains predominate in Guadalupian and Lopingian strata. This shift records diminishment of Ancestral Rocky Mountains (western) sources and growing predominance of sources to the south and southeast. These tectonic changes operated in concert with the growing influence of monsoonal circulation, which strengthened through Permian time. This resulted in a growing predominance of material sourced from uplifts to the south and southeast, but carried to the midcontinent by easterlies, southeasterlies, and westerlies toward the ultimate sink of the southern midcontinent.
\end{abstract}

Soreghan, M.J., Swift, M.M., and Soreghan, G.S., 2018, Provenance of Permian eolian and related strata in the North American midcontinent: Tectonic and climatic controls on sediment dispersal in western tropical Pangea, in Ingersoll, R.V., Lawton, T.F., and Graham, S.A., eds., Tectonics, Sedimentary Basins, and Provenance: A Celebration of William R. Dickinson's Career: Geological Society of America Special Paper 540, p. 1-XXX, https://doi.org/10.1130/2018.2540(28). @ 2018 The Geological Society of America. All rights reserved. For permission to copy, contact editing @ geosociety.org. 


\section{INTRODUCTION}

The Permian records a time of fundamental reorganization of climatic and tectonic conditions across Pangea. The widespread orogenesis associated with Pangean assembly greatly diminished in the latest Carboniferous; by Permian time, the supercontinent began unraveling in rift zones that initiated first in eastern Pangea and parts of Gondwana (Frizon de Lamotte et al., 2015). The global icehouse of the Carboniferous yielded to full greenhouse conditions by Middle to Late Permian time (e.g., Crowell, 1999; Fielding et al., 2008), with attendant changes in greenhouse gases (e.g., Foster et al., 2017), atmospheric circulation patterns (e.g., Parrish, 1993; M. Soreghan et al., 2002; Tabor and Montañez, 2002, 2004), and tropical aridity (e.g., Tabor and Poulsen, 2008). However, a better understanding of the effects and interactions of these changes through the Permian requires improved understanding of paleoenvironmental changes in western equatorial Pangea, including transport pathways and mechanisms during deposition.

The midcontinent of North America (west-central Pangea; Fig. 1) preserves up to $2 \mathrm{~km}$ of Permian red beds, intercalated evaporites, and rare thin carbonates (McKee and Oriel, 1967). For $>70 \mathrm{yr}$, these strata have been interpreted as tidal-flat and marginal-marine deposits, a generalization based predominantly on the presence of evaporites and rare carbonates (Hills, 1942; Ham, 1960; Fay, 1962, 1964; Johnson, 1967, 1988; McKee and Oriel, 1967). The volumetrically dominant siliciclastic component, however, has been largely ignored. An alternate paleogeographic reconstruction for the Permian in this region is slowly emerging from facies analyses, beginning with evaporites, which are now recognized as the products of saline lakes (Benison et al., 1998; Benison and Goldstein, 2000, 2001). More recent attention has turned to the rather monotonous, but pervasive, fine-grained red beds of the region, which have increasingly been recognized to preserve continental environments, and the predominant influence of wind (references below). This emerging revision of the large-scale paleogeomorphology of the midcontinent impacts reconstructions of the origin, provenance, and transport of vast fine-grained sediment deposits, both here and in regions distal from source areas.

This study focused on strata in Oklahoma, the Texas Panhandle, and Kansas (Fig. 1). We combined provenance data from published and unpublished studies of Permian outcrops across central and western Oklahoma with new provenance data from a long research core (the "Rebecca K. Bounds" core) drilled on the shelf of the Anadarko Basin (western Kansas) to obtain a semicontinuous record of provenance changes through the Permian of the North American midcontinent. We also include brief facies descriptions and interpretations of the core and outcrops, drawing upon both recent detailed facies analyses of correlative units and preliminary reinterpretations of units that have not attracted modern attention. These results shed new light on the predominance of eolian sedimentation within Permian strata of the midcontinent and changes in paleodispersal patterns related to both tectonic and climatic changes during the Permian.

\section{GEOLOGIC BACKGROUND}

\section{Tectonic Setting}

During the Mississippian, Pennsylvanian, and Permian, Laurentia (which included North America) collided diachronously with Gondwana, resulting in development of the Appalachian-Ouachita-Marathon, Mauritanide, and HercynianVariscan orogenic belts (Fig. 1; also known as the Central Pangean Mountains; Scotese et al., 1979; Ziegler et al., 1979; Thomas, 1985; Scotese and McKerrow, 1990). Additionally, the evolving stress regime related to this event and/or events farther west potentially contributed to coupled uplift and basin subsidence along high-angle faults far inboard of plate boundaries of western Pangea, forming the Ancestral Rocky Mountains west of the midcontinent region, but also including the Amarillo-Wichita uplift and adjoining Anadarko Basin and Hugoton embayment in the Pennsylvanian section of the midcontinent region (Fig. 1; Kluth and Coney, 1981; Trexler et al., 2004; Leary et al., 2017). The Nemaha Ridge (Fig. 1), which was likely a reactivated Precambrian structure, also experienced uplift during the Carboniferous, but it was subsequently buried by Upper Pennsylvanian strata (Steeples, 1989). Collisional orogenesis in the western terminus of the Central Pangean Mountains slowed by the end of the Pennsylvanian (Scotese et al., 1979; Scotese and McKerrow, 1990; Viele and Thomas, 1989). Many of the intraplate uplifts began to subside in the Permian, and onlap of Permian strata may have effectively buried the Ancestral Rocky Mountains and Amarillo-Wichita uplifts by the late Leonardian or early Guadalupian (Soreghan et al., 2012). The mechanism for the Permian subsidence remains poorly understood.

\section{Paleoclimate}

The climate of Pangea during the late Paleozoic exhibited tremendous change over various temporal and spatial scales. By late Mississippian through earliest Permian time, glaciation occurred across the Gondwanan continent; whether this represented a single large ice sheet or multiple ice centers is debated (Fielding et al., 2008). Paleolatitudinal reconstructions indicate that continental glaciation extended at times to as low as $32^{\circ} \mathrm{S}$ (Evans, 2003), and ice volume appears to have peaked in the Early Permian (Frakes, 1992). Although debated, evidence also exists for glaciation in moderate-elevation highland (alpine) settings of the tropics, in both western and eastern equatorial Pangea (Becq-Giraudon et al., 1996; G.S. Soreghan et al., 2008a, 2014). Ice volume appears to have varied through growth and decay of ice centers through the Carboniferous and into the Early Permian (Montañez and Poulsen, 2013), followed by retreat, and then ultimate collapse to alpine and polar settings of Australia by the Guadalupian (Veevers and Powell, 1987; Crowell, 1999; Fielding et al., 2008).

In low-latitude and low-elevation settings, high-frequency eustatic variations and attendant changes in depositional 


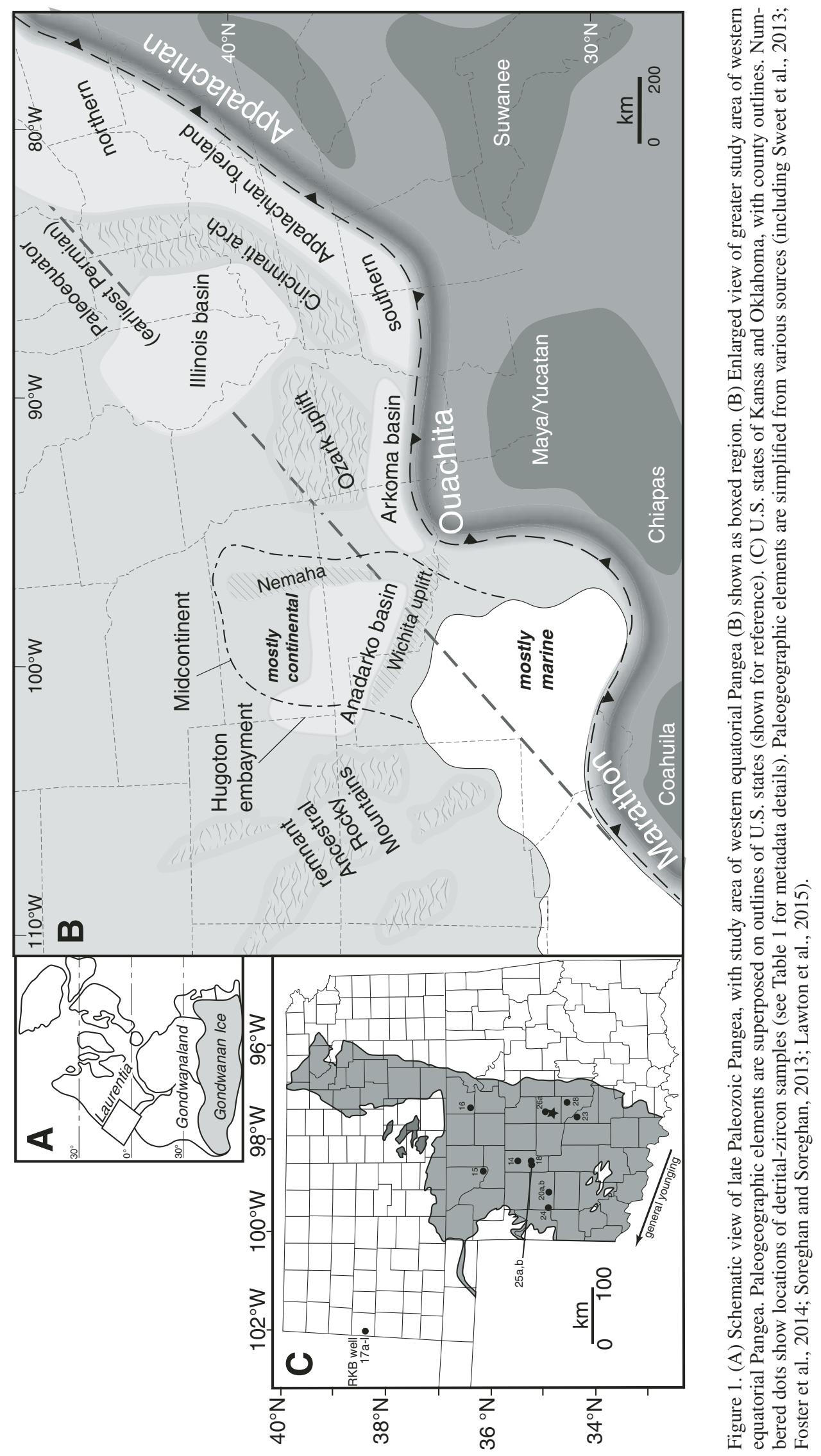


environments resulted from variations in glacial volume (e.g., Heckel et al., 1998; Heckel, 2008). A growing body of literature has linked these glacioeustatic changes to changes in lowlatitude climate (e.g., changes in precipitation-evaporation balance; Soreghan, 1994; Tandon and Gibling, 1994; Allen et al., 2011; M.J. Soreghan et al., 2014), and attendant temporal and spatial shifts in depositional facies.

Coincident with the maximal extent of glaciation, and, to a certain extent, enhanced tectonism, atmospheric circulation underwent a fundamental shift in the latest Pennsylvanian, from a zonal-dominated regime, marked by prevailing easterly winds at low latitudes, to a monsoonal pattern, marked by both easterly and (seasonal) westerly winds at low latitudes (Parrish, 1993; M. Soreghan et al., 2002; Tabor and Montañez, 2002; M.J. Soreghan et al., 2008, 2014; Heavens et al., 2015). On a long-term scale, many authors have recognized increasing aridity in western tropical Pangea from latest Pennsylvanian through Permian time (e.g., Briden and Irving, 1964; Kessler et al., 2001; Piper and Link, 2002; Tabor and Montañez, 2004; Tabor and Poulsen, 2008) and elevated temperatures in the later Permian in particular (Zambito and Benison, 2013). Regardless of the causes for these changes, part of the evidence comes in the form of the increasing abundance of eolian silt (paleo-loess) and eolian sand preserved in the stratigraphic record of the midcontinent and surrounding regions (and even farther afield) through late Pennsylvanian-Permian time (Boucot et al., 2013).

\section{Paleogeography and Stratigraphy}

In the Permian, the North American midcontinent (central Pangea) was bordered by the Ancestral Rocky Mountains and Amarillo-Wichita uplifts to the west and southwest, the Marathon orogenic belt to the south and southwest, and the Ouachita and Appalachian orogens to the southeast and east (respectively). To the northwest, there was a gradational transition to marine/ sabkha environments, as recorded in the Phosphoria Formation (Piper and Link, 2002). The midcontinent formed a relatively flat-lying, low-elevation subsiding area that remained nearly equatorial through the late Paleozoic, moving from $\sim 5^{\circ} \mathrm{S}$ in the latest Pennsylvanian to $2^{\circ} \mathrm{N}-4^{\circ} \mathrm{N}$ in the Early Permian (Fig. 1; Tabor and Poulsen, 2008). New data from the Rebecca K. Bounds (RKB) core suggest paleolatitudes of $6^{\circ} \mathrm{N}-10^{\circ} \mathrm{N}$ from the earliest Guadalupian to the end of the Permian (Foster et al., 2014). The Anadarko Basin and Hugoton embayment formed subsiding regions within this area; to the east, the Ozark dome, uplifted during the Ouachita orogeny, likely persisted as a low-relief positive area in the Permian (Fig. 1; Sutherland, 1988).

Permian strata are up to $\sim 2 \mathrm{~km}$ thick in the keel of the Anadarko Basin (Soreghan et al., 2012); however, a dearth of biostratigraphic data makes it difficult to precisely date some Permian strata of the midcontinent, which complicates regional correlations and assignment of formations/groups to stage-level precision (Zambito et al., 2012). Poor exposure, evaporite dissolution, and low dips also complicate regional correlations. These factors have led to conflicting and diachronous assignments of group and formation names and/or the use of different unit names regionally (Fig. 2).

In Kansas and in west-central Oklahoma (Fig. 2), uppermost Pennsylvanian through lowest Permian strata (i.e., the Chase and Council Grove Groups) predominantly consist of limestone and shale cyclothems of mixed continental-marine origin, but upward through the Permian, these strata yield to red beds and evaporites, including anhydrite/gypsum beds and bedded halite. In the RKB core, the overlying Sumner Group contains mostly red siltstone and shale, along with minor gray shale, gypsum, and anhydrite (Fig. 3; Zambito et al., 2012; Giles et al., 2013). In outcrops of central Oklahoma, the Garber Sandstone forms a prominent unit within the Sumner Group, between the Wellington Formation and Hennessey Shale (Simpson et al., 1999). In the RKB core, the Nippewalla Group overlies the Sumner Group and consists (predominantly) of red claystone, siltstone, and sandstone interbedded with (subordinate) displacive evaporites, specifically halite and gypsum/anhydrite (Benison and Goldstein, 2001; Zambito et al., 2012; Sweet et al., 2013).

In western Oklahoma, however, stratigraphic terminology varies, with the El Reno Group lying above the Sumner Group. The El Reno Group is lithologically similar to the Nippewalla Group, but it includes the Duncan Sandstone, in addition to mudstone and minor evaporite facies. Stratigraphically above the Dog Creek Shale (top Nippewalla Group in Kansas), there lies the red-orange and red-brown Whitehorse Sandstone, the anhydrite and orange mudstone of the Day Creek Dolomite, and the orange and white sandstone and siltstone of the Big Basin Formation (Zambito et al., 2012). In western Oklahoma, however, the Marlow Sandstone is also present and overlain by the Cloud Chief Formation, and the Doxy and Elk City Formations, which likely record Lopingian time (Fig. 2). In the RKB core, an unconformity separates the Guadalupian Big Basin Formation from overlying buff-colored sandstone interpreted to be the Jurassic Entrada Sandstone (Zambito et al., 2012); our detritalzircon data confirm this.

\section{METHODS}

In this study, we integrated data collected from the RKB core (Kansas), which provides unambiguous stratigraphic superposition, with data collected from outcrops scattered across the low-dip, low-relief exposures of Oklahoma.

The RKB core, which was drilled in Greeley County, Kansas $\left(38.48963^{\circ} \mathrm{N}, 101.97456^{\circ} \mathrm{W}\right)$, by the research arm of the Amoco Production Company in 1988, recovered 1800 vertical feet ( $\sim 550 \mathrm{~m})$ of Permian strata (Benison et al., 2013). The core recovery rate exceeds $98 \%$ for the studied interval and was likely drilled with salt-saturated fluids, as halite is well preserved through the core (Zambito et al., 2012). Amoco undertook biostratigraphic analysis before ultimately transferring the core to its current location at the Kansas Geological Survey in Lawrence, Kansas (Zambito et al., 2012). 


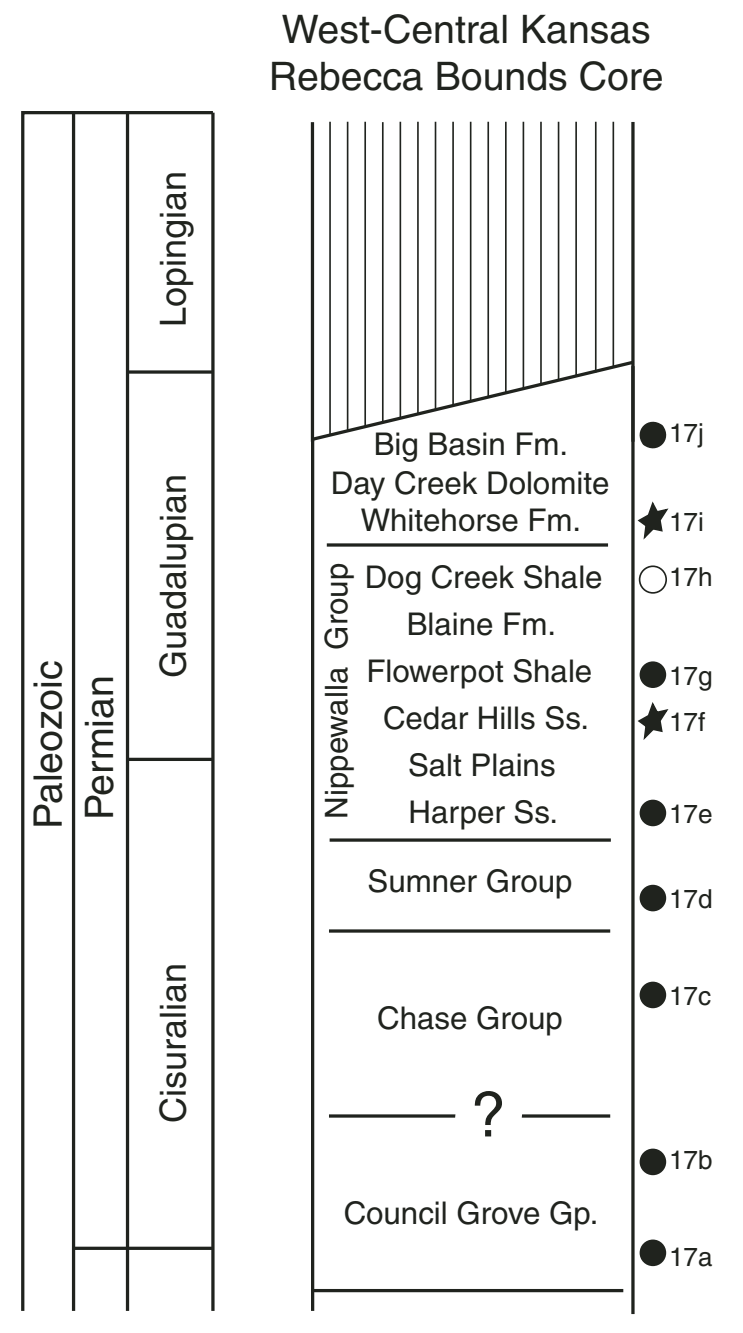

\section{Western and Central Oklahoma Outcrop Belt}

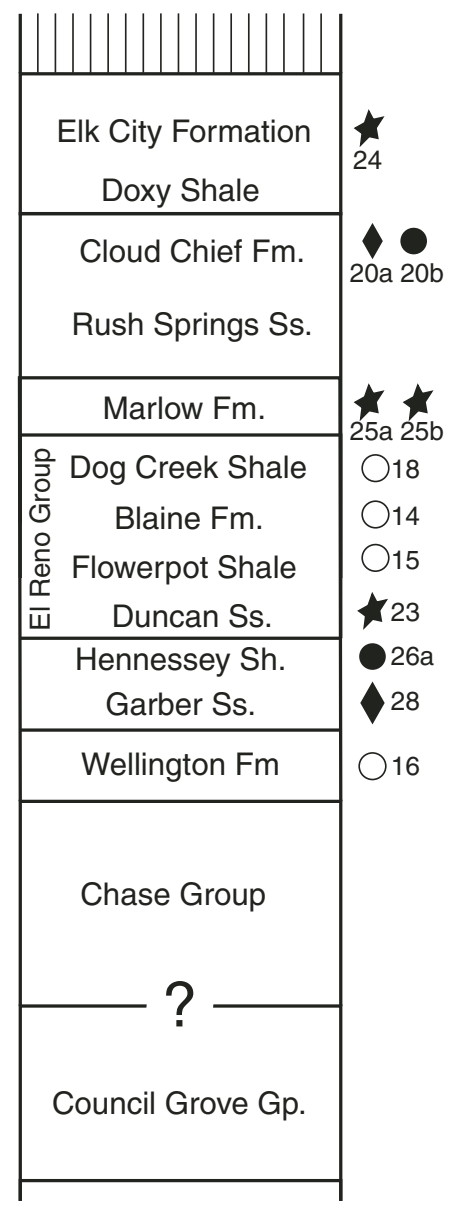

Figure 2. Chronostratigraphy for Rebecca K. Bounds (RKB) core of Kansas (left), and Oklahoma outcrop samples (right), with stratigraphic locations of all detrital-zircon samples. Numbers of samples are keyed to metadata presented in Table 1. Circles are eolian siltstone, stars are eolian sandstone, and diamonds are fluvial sandstone. Kansas column is from Zambito et al. (2012); Oklahoma column is from Foster et al. (2014). Fm-Formation; Gp-Group; Ss-Sandstone; Sh-Shale.
The studied interval of the RKB core contains strata ranging from the Chase and Council Grove Groups (Wolfcampian) to the Entrada(?) Formation (Upper Jurassic), with a substantial unconformity between Permian and Jurassic strata (Fig. 3). The core was examined and sampled, and a full description of the core, including lithology, nature of contacts and unconformities, and stratigraphic designations, is available in two recent Kansas Geological Survey reports (Zambito et al., 2012; Benison et al., 2013). Samples taken for detrital-zircon geochronology are depicted on Figure 3 and in Table 1.

To supplement these data and provide more spatial coverage of the midcontinent region, we collected samples of siliciclastic facies from outcrops of western and central Oklahoma for detrital-zircon analysis, which complements previously collected and published outcrop-based studies (Table 1; Giles et al., 2013; Sweet et al., 2013; Foster et al., 2014). The newly analyzed outcrop samples included the: (1) Garber Sandstone and Hennessey Shale (Cisuralian); (2) Duncan Sandstone (Guadalupian); (3) Marlow Formation (Guadalupian); (4) Cloud Chief Formation (Lopingian); and (5) Elk City Formation (Lopingian). Figure
2 depicts stratigraphic ages and the temporal relationships with sampled units in the RKB core. The complete data set of all previously unpublished zircon data from both sites is presented in Table DR1. ${ }^{1}$

For the core samples, we conducted detailed lithologic descriptions of each interval $(\sim 1 \mathrm{~m})$ encompassing the sample horizons selected for detrital-zircon analysis (see below); these supplemented the formation-scale descriptions in Zambito et al. (2012). Representative thin sections were made for samples selected for detrital-zircon geochronology. For outcrop samples, we recorded general facies in the sampled outcrops, and we integrated these with observations from other outcrops regionally, as well as any published observations, to facilitate environmental interpretations.

${ }^{1}$ GSA Data Repository Item 2018394, U-Pb age data of detrital zircon samples, is available at www.geosociety.org/datarepository/2018/, or on request from editing@geosociety.org or Documents Secretary, GSA, P.O. Box 9140, Boulder, CO 80301-9140, USA. 


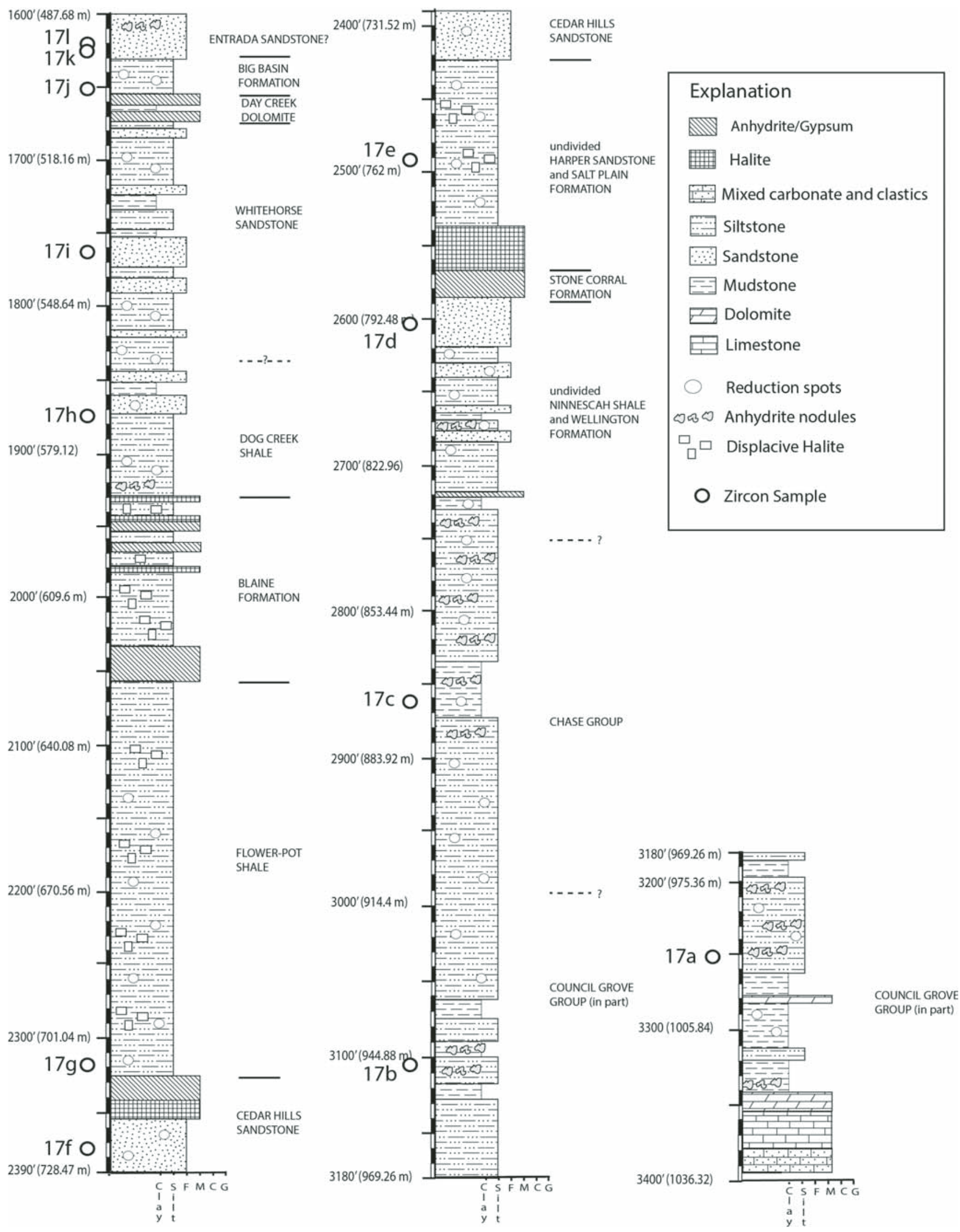

Figure 3. Lithologic log for Rebecca K. Bounds (RKB) core, showing subsurface depths (in ft [as originally recorded during drilling] and meters), unit names, and sampling horizons. Sample numbers are keyed to metadata presented in Table 1. Grain size abbreviations: cclay; s—silt; f—-fine sand; m-medium sand; c—coarse sand; g—gravel. 
TABLE 1. INFORMATION FOR DETRITAL-ZIRCON SAMPLES USED IN THIS STUDY

\begin{tabular}{|c|c|c|c|c|c|c|}
\hline DZ sample no. & Location & Stage age & Group/formation & Lithology & $\begin{array}{c}\text { Concordant age } \\
\text { (Ma) }\end{array}$ & Source \\
\hline 14 & Oklahoma & Guadalupian & Blaine Fm & Eolian siltstone & 48 & Sweet et al. (2013) \\
\hline 15 & Oklahoma & Guadalupian & Flowerpot Sh & Eolian siltstone & 71 & Sweet et al. (2013 \\
\hline 16 & Oklahoma & Cisuralian & Wellington Fm & Eolian siltstone & 79 & Giles et al. (2013) \\
\hline $17 a$ & Kansas & Cisuralian & Council Grove Gp & Eolian siltstone & 85 & This study \\
\hline $17 \mathrm{~b}$ & Kansas & Cisuralian & Council Grove Gp & Eolian siltstone & 104 & This study \\
\hline $17 \mathrm{c}$ & Kansas & Cisuralian & Chase Gp & Eolian siltstone & 86 & This study \\
\hline $17 d$ & Kansas & Cisuralian & Sumner Gp & Eolian siltstone & 92 & This study \\
\hline $17 \mathrm{e}$ & Kansas & Cisuralian & Harper Ss & Eolian siltstone & 112 & This study \\
\hline $17 f$ & Kansas & Guadalupian & Cedar Hills Ss & Eolian sandstone & 89 & This study \\
\hline $17 \mathrm{~g}$ & Kansas & Guadalupian & Flowerpot Sh & Eolian siltstone & 94 & This study \\
\hline $17 \mathrm{~h}$ & Kansas & Guadalupian & Dog Creek Fm & Eolian siltstone & 90 & Foster et al. (2014) \\
\hline $17 i$ & Kansas & Guadalupian & Whitehorse Ss & Eolian sandstone & 88 & This study \\
\hline $17 \mathrm{j}$ & Kansas & Guadalupian & Big Basin Fm & Eolian siltstone & 61 & This study \\
\hline $17 \mathrm{k}$ & Kansas & Mesozoic & Unknown & Not studied & 99 & This study \\
\hline $17 \mathrm{~L}$ & Kansas & Mesozoic & Entrada? & Not studied & 89 & This study \\
\hline 18 & Oklahoma & Guadalupian & Dog Creek Fm & Eolian siltstone & 85 & Foster et al. (2014) \\
\hline $20 a$ & Oklahoma & Lopingian & Cloud Chief Fm & Fluvial sandstone & 177 & Gergurich (2015) \\
\hline $20 \mathrm{~b}$ & Oklahoma & Lopingian & Cloud Chief Fm & Eolian siltstone & 106 & Gergurich (2015) \\
\hline 23 & Oklahoma & Guadalupian & Duncan Ss & Eolian sandstone & 103 & This study \\
\hline 24 & Oklahoma & Lopingian & Elk City Fm & Fluvial sandstone & 158 & This study \\
\hline $25 a$ & Oklahoma & Guadalupian & Marlow Fm & Eolian sandstone & 207 & This study \\
\hline $25 b$ & Oklahoma & Guadalupian & Marlow Fm & Eolian sandstone & 211 & This study \\
\hline $26 a$ & Oklahoma & Cisuralian & Hennessey Sh & Eolian siltstone & 94 & This study \\
\hline 28 & Oklahoma & Cisuralian & Garber Ss & Fluvial sandstone & 104 & This study \\
\hline
\end{tabular}

Samples were processed and analyzed at the Arizona LaserChron center. Samples were crushed using standard rock pulverization techniques, followed by standard density and magnetic separation, and samples were mounted without bias to the size or shape of the grains with an external zircon standard in 1-in.diameter ( 2.5-cm-diameter) epoxy disks (Johnston et al., 2009). Sample mounts were imaged on a scanning electron microscope (SEM) with a cathodoluminescence (CL) detector in order to characterize chemical zoning and identify core-rim relationships in unknown grains (Johnston et al., 2009). Approximately 100200 randomly selected zircon grains from each sample (where possible) were analyzed using a laser-ablation-multicollectorinductively coupled plasma-mass spectrometer (LA-MC-ICPMS) that measures $\mathrm{U}-\mathrm{Th}-\mathrm{Pb}$ isotopes. Isotope ratios were compared and filtered according to precision (at a 10\% cutoff) and discordance (20\% cutoff $/ 10 \%$ reverse cutoff) to account for possible $\mathrm{Pb}$ loss or inheritance issues. The ${ }^{206} \mathrm{~Pb} /{ }^{207} \mathrm{~Pb}$ ratios are given for zircons older than $900 \mathrm{Ma} ;{ }^{206} \mathrm{~Pb} /{ }^{238} \mathrm{U}$ ratios provide the best ages of zircon younger than $900 \mathrm{Ma}$, owing to low intensity of the ${ }^{207} \mathrm{~Pb}$ signal (Gehrels et al., 2006). The data were plotted on relative-age probability plots in order to identify significant age clusters, which can assist in determining sedimentary provenance (Gehrels et al., 2006).

\section{RESULTS}

\section{RKB Core Samples (Subsurface)}

The following are lithologic descriptions of the samples from the interval enclosing the detrital-zircon samples (Fig. 3), although the broader lithologic context, and previously pub- lished analyses for coeval strata of the region lend further stratigraphic context that facilitated ultimate interpretations. Sample names used here are keyed to the subsurface depths (in $\mathrm{ft}$, as originally marked on the core; e.g., RKB 3251 refers to $3251 \mathrm{ft}$ [991 m] subsurface). Primary groupings of U-Pb ages for each sample are noted; Table 2 lists percentages of detrital-zircon ages in each sample, separated into major age groupings (with interpretations of source regions for each grouping provided in the text). Figure 4 shows age-probability plots for each sample in stratigraphic order.

\section{Sample 17a-RKB 3251 (Council Grove Group, Cisuralian)}

Strata encasing RKB 3251 (991 m subsurface) consist of dark red-brown mudstone that is internally massive, with only rare disrupted laminae, and local reduction spots and associated anhydrite nodules (Fig. 5A). In thin section, quartzofeldspathic silt and very fine sand $(<100 \mu \mathrm{m})$ grains float within a very fine, red-brown clayey matrix with locally abundant dolomite cement (Fig. 6A).

The fine grain size and massive character are consistent with interpretation of this unit as paleo-loess; Dubois et al. (2012) previously interpreted siliciclastic intervals of the Council Grove Group in southwestern Kansas to record eolian (predominantly loess) deposition. The abundant clay matrix surrounding grains suggests a porphyroskelic fabric (a pedogenic fabric in which skeletal grains float within a dense plasma groundmass) (cf. Brewer, 1976) produced by incipient pedogenesis, also consistent with accumulation of eolian silt in a continental (loess) setting.

RKB 3251 contains a large group (18\%) of zircon ages between 740 and $560 \mathrm{Ma}$, with a peak of five zircon grains 


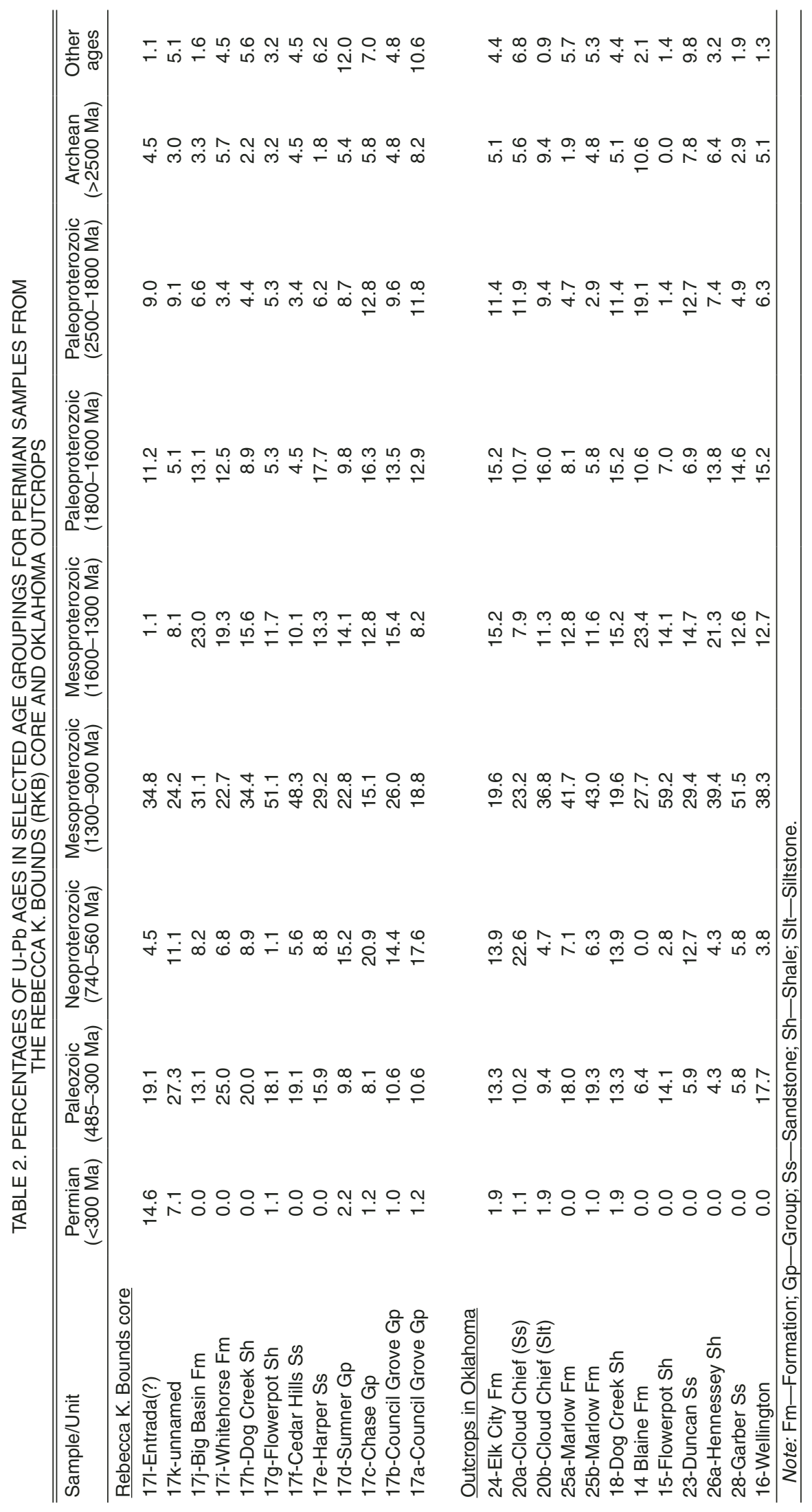




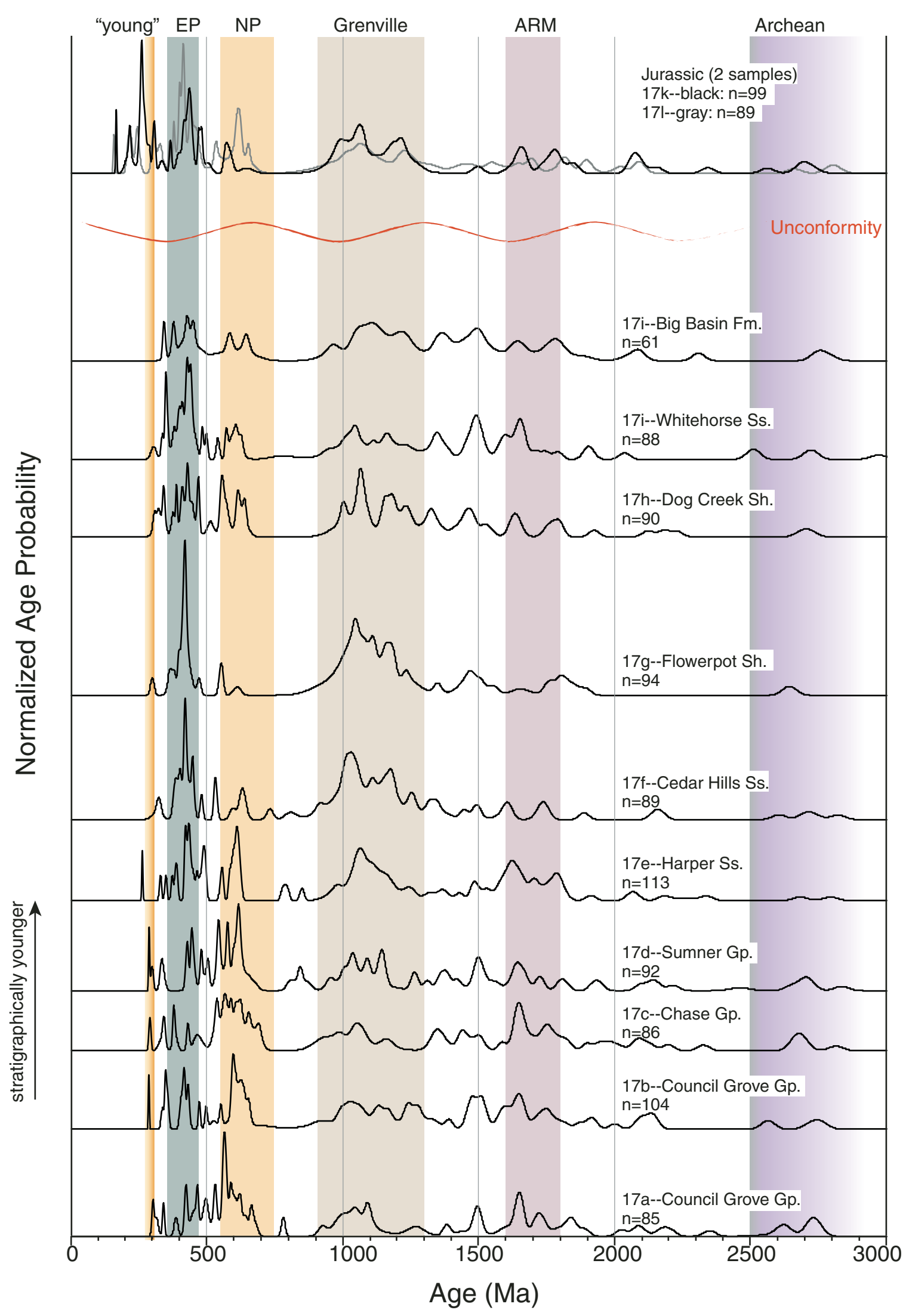

Figure 4. Relative probability plots of detrital-zircon data for samples from Rebecca K. Bounds (RKB) core. Age labels at top refer to age groupings discussed in text. Fm—Formation; Gp—Group; Ss—Sandstone; Sh—Shale; EP—early Paleozoic; NP-Neoproterozoic; ARM-Ancestral Rocky Mountains. 


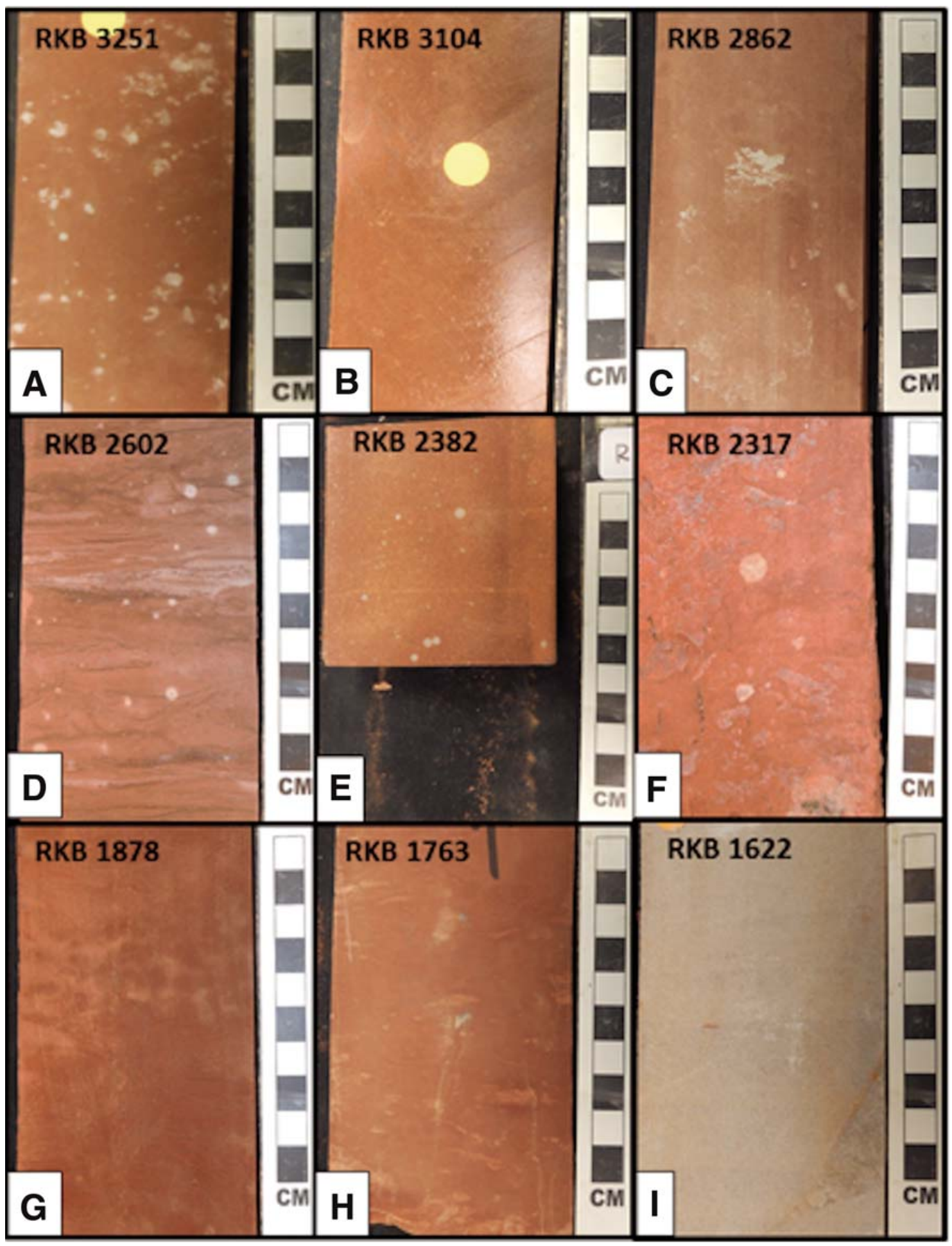

Figure 5. Photos of representative samples from Rebecca K. Bounds (RKB) core. RKB labels refer to core depths (see text for details). (A) Massive mudstone (Council Grove Group), with local reduction spots. (B) Massive siltstone (Council Grove Group). (C) Massive siltstone (Chase Group). (D) Wispy laminated siltstone of Sumner Group. (E) Massive to faintly laminated, fine-grained sandstone (Cedar Hills Sandstone). (F) Siltstone with wispy laminae and subvertical (root?) traces (Flowerpot Shale). (G) Mottled siltstone with (lower) faint disrupted laminae (Dog Creek Shale). (H) Siltstone with disrupted laminae and mud chips (Whitehorse Sandstone). (I) Medium-grained sandstone (Entrada Formation). 


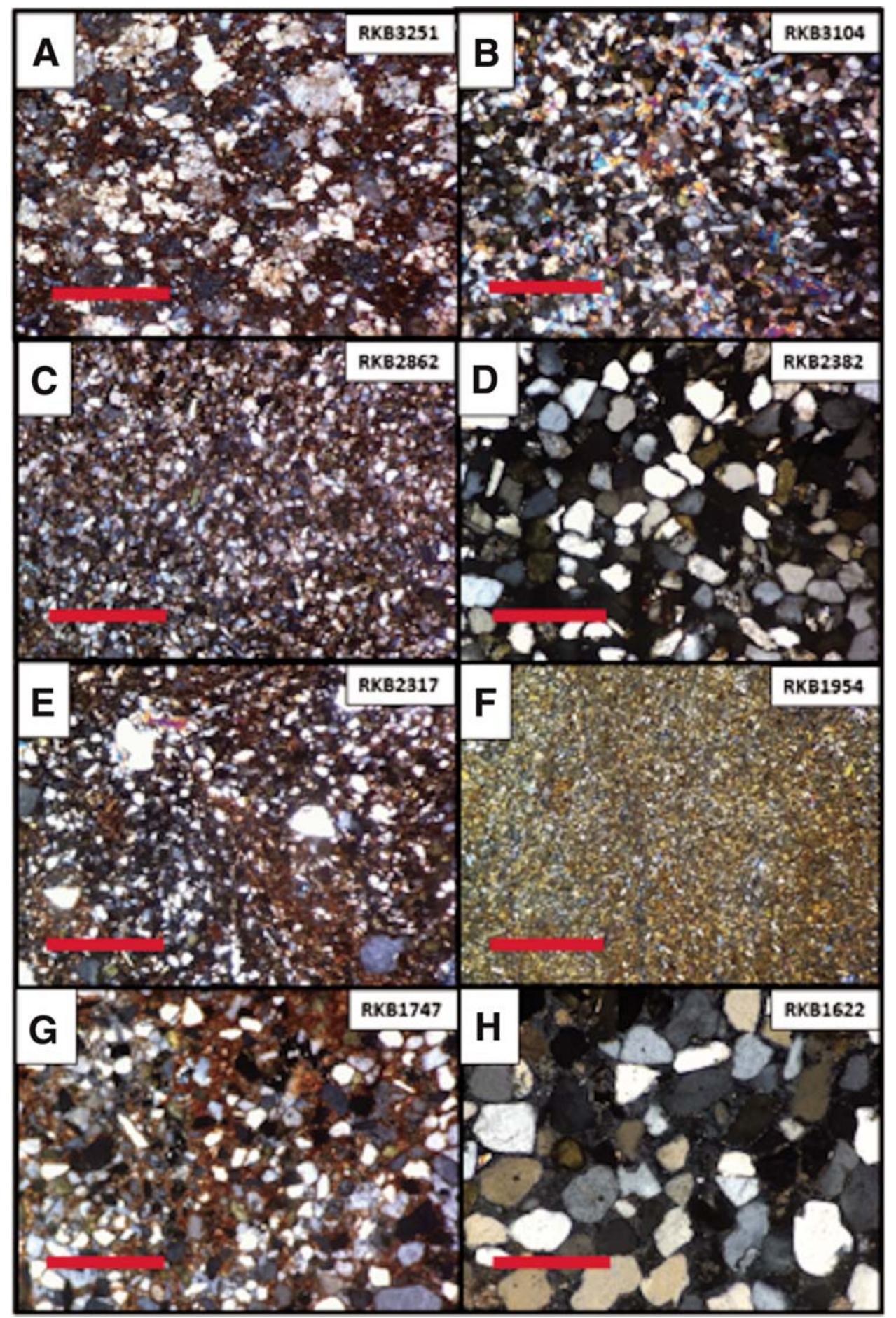

Figure 6. Photomicrographs of representative samples from Rebecca K. Bounds (RKB) core. All images are in crosspolarized light; scale bars are all $4 \mathrm{~mm}$. RKB labels refer to core depths. (A) Silt and very fine sand within a porphyroskelic (incipient pedogenic) fabric (Council Grove Group). (B) Moderately sorted silt within a massive siltstone (Council Grove Group). (C) Silt grains with clay coats (incipient pedogenic; Chase Group). (D) Well-sorted sand (Cedar Hills Sandstone). (E) Silt surrounded by locally aligned (pedogenic) clay matrix (Flowerpot Shale). (F) Massive mudstone (Dog Creek Shale). (G) Very finegrained sand surrounded with a clay plasma (pedogenic; Whitehorse Sandstone). $(\mathrm{H})$ Well-rounded and sorted quartzose sand grains (Entrada Formation).

around $560 \mathrm{Ma}$ (Table 2; Fig. 4). Other notable age groupings include 1300-900 Ma (19\%), 485-300 Ma (12\%), 2500$1800 \mathrm{Ma}(12 \%)$, and 1800-1600 Ma (13\%).

\section{Sample 17b-RKB 3104 (Council Grove Group, Cisuralian)}

RKB 3104 (946.1 m subsurface) and enclosing strata consist of light red-orange, massive siltstone (Fig. 5B). In thin section, the sample consists of moderately sorted, subangular silt grains of quartzofeldspathic composition, cemented by poikilotopic anhydrite (Fig. 6B).

As above, the massive character and silt grain size suggest deposition as loess, consistent with other interpretations of massive siltstone intervals of the (correlative) Council Grove Group across southern Kansas (Dubois et al., 2012). 
RKB 3104 contains a large proportion of 1300-900 Ma grains (26\%) and 740-560 Ma grains (15\%; with a peak of five zircon grains around $595 \mathrm{Ma}$; Table 2; Fig. 4). The sample also contains 1800-1600 Ma grains (13.5\%) and 11\% 486-300 Ma grains, with one grain of Permian age $(286 \pm 2.9 \mathrm{Ma})$.

\section{Sample 17c-RKB 2862 (Chase Group, Cisuralian)}

Strata encasing RKB 2862 (872.3 m subsurface) consist of dark red-orange massive siltstone with local reduction spots and associated anhydrite nodules (Fig. 5C). In thin section, RKB 2862 consists of subangular silt with relatively abundant clay coatings on silt grains of quartzofeldspathic composition (Fig. 6C).

The massive character and silt grain size again suggest a loess origin for this sample, consistent with recent interpretations for correlative units in the region (Dubois et al., 2012), as noted above.

RKB 2862 contains a large proportion of 740-560 Ma ages (21\%) and 1800-1600 ages (16\%; Table 2; Fig. 4). Other notable age groupings include 1300-900 Ma (15\%) and 2500-1800 Ma (13\%), but relatively few 485-300 Ma ages (8\%). There is also one grain of Permian age.

\section{Sample 17d-RKB 2602}

\section{(Undifferentiated Sumner Group, Cisuralian)}

Sample RKB 2602 (793.1 m subsurface) consists of redorange siltstone permeated with discontinuous and wispy laminae (Fig. 5D). The latter may reflect mud cracks, or local root traces, because a large $(20 \mathrm{~cm})$ subvertical trace bifurcates the core in this interval.

The fine grain size, discontinuous laminae, and vertical (inferred root) trace suggest depositional processes consistent with mud-flat or ephemeral lake environments. The consistently fine grain size of enclosing units and lack of fluvial features suggest that the clastic material likely experienced eolian transport to the site of deposition, and ultimate preservation in an ephemerally wet environment, similar to interpretations for analogous facies of the roughly coeval Permian Wellington Formation in Oklahoma (Giles et al., 2013). As such, we interpret this unit to represent water-reworked paleo-loess.

RKB 2602 contains a large proportion of ages 1300$900 \mathrm{Ma}(23 \%)$ and 740-560 Ma (16\%; Table 2; Fig. 4). There are relatively few $485-300 \mathrm{Ma}(10 \%)$ ages and two grains of Permian age.

\section{Sample 17e-RKB 2490 (Harper Sandstone, Cisuralian)}

Strata enclosing RKB 2490 consist of red-orange to redbrown massive siltstone with common displacive halite. In outcrop, the Harper Sandstone includes both argillaceous siltstone and very fine silty sandstone (Zeller, 1968). No comprehensive facies treatments exist of this unit, but the very fine-grained, massive character is analogous to other units throughout the Permian section that bear positive evidence for eolian transport.

RKB 2490 consists of a large proportion of 1300-900 Ma (29\%) ages and 485-300 Ma ages (16\%; Table 2; Fig. 4). There are relatively few $740-560 \mathrm{Ma}(8.8 \%)$ ages and one grain of Permian age.

\section{Sample $17 f-R K B 2382$ \\ (Cedar Hills Sandstone, Guadalupian)}

Strata enclosing RKB 2382 (726.0 m subsurface) consist of light red-orange, fine- to medium-grained quartzose sandstone (Fig. 5E) that is friable, well sorted, and internally massive (Fig. 6D).

The well-sorted texture and internally massive character of the interval enclosing this sample is consistent with eolian transport, although it is difficult to constrain based on the core data alone. However, an eolian interpretation is consistent with the regional context, as Benison and Goldstein (2001) reported eolian sandstone facies as well as mud-flat facies from the Nippewalla Group (including the Cedar Hills Sandstone) in southcentral Kansas and north-central Oklahoma.

RKB 2382 consists of a large proportion (48\%) of grains with 1300-900 Ma ages (Table 2; Fig. 4). Other age groupings include zircon of 500-300 Ma (19\%; with a peak of eight grains around $418 \mathrm{Ma})$; there are relatively few grains 740-560 Ma $(6 \%)$, and 1800-1600 Ma (4.5\%); there are no Permian zircon grains.

\section{Sample 17g-KB 2317 (Flowerpot Shale, Guadalupian)}

Strata encasing RKB 2317 (706.2 m subsurface) consist of red-orange siltstone to mudstone with disrupted wispy laminae and subvertical traces $(0.2-0.9 \mathrm{~m}$ long) filled with halite (Fig. $5 \mathrm{~F})$, as well as small $(1 \mathrm{~mm}-2 \mathrm{~cm})$ reduction spots and anhydrite nodules. In thin section, a clay matrix that appears to be locally aligned surrounds framework grains that are predominantly quartzose (Fig. 6E).

The fine-grained texture is consistent with eolian transport, and the vertical traces and local clay alignment suggest pedogenic overprinting - features common to loess deposition. Sweet et al. (2013) inferred an eolian origin, with common paleosols for the Flowerpot Shale in northwest Oklahoma, based on features similar to those documented here; this interpretation is also consistent with regional interpretations of Nippewalla Group units by Benison and Goldstein (2001).

RKB 2317 contains a large proportion (51\%) of 1300-900 Ma ages (Table 2; Fig. 4), and abundant ages of 485-300 Ma (18\%; with a peak of seven zircon grains around $417 \mathrm{Ma})$. There are relatively few grains with ages of 1800-1600 Ma (5\%) and 740$560 \mathrm{Ma}(1 \%)$; there is one Permian-age grain.

\section{Sample 17h-RKB 1878 (Dog Creek Shale, Guadalupian)}

Sample RKB 1878 (572.5 m subsurface) and enclosing strata consist of mottled light-orange siltstone that is predominantly massive, but with local, faint disrupted laminae and apparent rip-up clasts (Fig. 5G). Unlike many of the sampled intervals stratigraphically below RKB1878, these strata do not contain evaporite veins or nodules.

The fine grain size is consistent with the eolian interpretation, although the disrupted laminae may record mud cracks and 
thus eolian delivery of fine sediment into a shallow lacustrine or mud-flat environment. In a more comprehensive treatment of the Dog Creek Shale at an outcrop in Oklahoma, Foster et al. (2014) inferred likely eolian transport and mud-flat deposition (with common pedogenesis) for analogous facies.

RKB 1878 contains a large population (34\%) of ages of 1300-900 Ma (Table 2; Fig. 4). There are also many ages of 500-300 Ma (20\%), with a maximum peak at $426 \mathrm{Ma}$. Other age groupings contain relatively few zircon grains, such as 750-560 Ma (9\%) and 1800-1600 Ma (9\%). There are no Permian-age grains.

\section{Sample 17i-RKB 1763}

(Whitehorse Sandstone, Guadalupian)

Sample RKB 1763 (537.4 m subsurface) and enclosing strata comprise a red-brown siltstone with disrupted laminae and possible rip-up clasts (Fig. $5 \mathrm{H})$. Local cross-bedding $(\sim 5 \mathrm{~cm}$ amplitude) occurs above the sampled interval, and large blocky fractures (inferred ped structures) occur below the sampled interval. In thin section, quartzofeldspathic framework grains are surrounded in areas by a clay plasma (Fig. 6G).

The disrupted laminae, rip-up clasts, and local crossstratification suggest deposition in an environment with water, but the clay plasma suggests local influence of pedogenesis, and thus, a mud-flat environment. In outcrops in Oklahoma, recent studies on the Whitehorse Sandstone have inferred environments ranging from eolian dune to restricted (ephemeral) lacustrine, on the basis of similar features (Kocurek and Kirkland, 1998; Poland and Simms, 2012).

RKB 1763 contains zircon with ages primarily 500$300 \mathrm{Ma}(25 \%$; with a peak of six zircon grains around $420 \mathrm{Ma})$ and 1300-900 Ma (23\%; Table 2; Fig. 4). The sample also includes 1800-1600 Ma zircon (12.5\%), and 740-560 Ma zircon $(7 \%)$. There are no Permian-age grains.

\section{Sample 17j-KB 1651 (Big Basin Formation, Guadalupian)}

Sample RKB 1651 consists of red-orange to red-brown siltstone, sandy siltstone, and fine-grained, feldspathic sandstone with distinct, thin subhorizontal gypsum veins. Similar to the Harper Sandstone, no comprehensive facies studies have been published on this unit, but the facies context visible in the core (i.e., very fine-grained massive character) is reminiscent of other units throughout the Permian section with evidence for eolian transport.

RKB 1651 zircon primarily has 1300-900 Ma ages (31\%) and roughly equal numbers (13\%) of 485-300 Ma and 1800-1600 Ma zircon (Table 2; Fig. 4). There are no Permianage grains.

\section{Sample $17 l$ and $17 k-R K B 1622$ and 1628 (Entrada Sandstone, Jurassic)}

Sample RKB 1622 (494.4 m subsurface) consists of buffcolored, medium- to coarse-grained, quartzose sandstone exhibiting sets (up to $0.6 \mathrm{~m}$ ) of planar cross-stratification (Fig.
5I), whereas RKB 1628 is more fine grained. In thin section, RKB 1622 contains subrounded to well-rounded grains of primarily quartz (Fig. 6H). The well-sorted texture, grain rounding, and cross-stratification are consistent with an eolian interpretation, such as that which characterizes the Entrada Formation across the Colorado Plateau (Peterson, 1988); however, no outcrop data exist in the region to supplement the limited observations available from core.

Both samples are likely Jurassic, based on abundant Mesozoic grains in both samples (Fig. 4), although the strata could be younger. Both samples also contain abundant 1300-900 Ma (24-35\%, Table 2), and 485-300 Ma zircon (19\%-27\%). Owing to our focus in this paper on the Permian, we do not consider these samples further, but we include these data as a valuable (and rare) glimpse into the Jurassic section of the midcontinent.

\section{Outcrop Samples from Oklahoma}

The following lithologic descriptions focus on detritalzircon samples from outcrops in Oklahoma, and they are placed in the context of published analyses for coeval strata in the region. Again, the primary groupings of U-Pb ages for each sample are highlighted in the sample descriptions, summarized in Table 2, and depicted in Figure 7 as age-probability plots.

\section{Sample 16-Wellington Formation (Cisuralian, Oklahoma)}

The Wellington Formation sample was collected from a quarry outcrop exposure of the Midco Member, a massive siltstone. Enclosing strata consist of mudstone varying from reduced to oxidized colors, and laminated to massive, with evidence for pedogenic overprints, especially in the more massive units (Fig. 8A). Recent interpretations for environment(s) favor ultimate deposition in lacustrine, mud-flat, and loess settings, with eolian delivery of the fine-grained clastics to these related environments (Giles et al., 2013); we follow that interpretation.

The Wellington siltstone sample consists primarily of 1300 900 Ma zircon (38\%), but also with abundant 485-300 Ma zircon (18\%) and 1800-1600 Ma zircon (15\%; Table 2; Fig. 7). There are no Permian-age grains.

\section{Sample 28-Garber Sandstone (Cisuralian, Oklahoma)}

The Garber Sandstone sample, collected from a road-cut exposure, consists of very fine-grained, orange-red to red-brown sandstone in beds up to $1.5 \mathrm{~m}$ thick, capped with laminated silty sandstone and siltstone in intervals 2.5-3 m thick. Some beds exhibit lateral-accretion surfaces and erosive bases marked by mud-clast conglomerate, whereas others exhibit thin planar laminations (Fig. 8B). The Garber Sandstone has been interpreted to record fluvial deposition, evinced by sandstone channels mapped in the subsurface of central Oklahoma (Simpson et al., 1999); this is consistent with lateral-accretion bedding and mud-clast conglomerate facies. However, possible eolian transport for much of the sediment cannot be ruled out, and no comprehensive facies analysis has been conducted on this unit. 


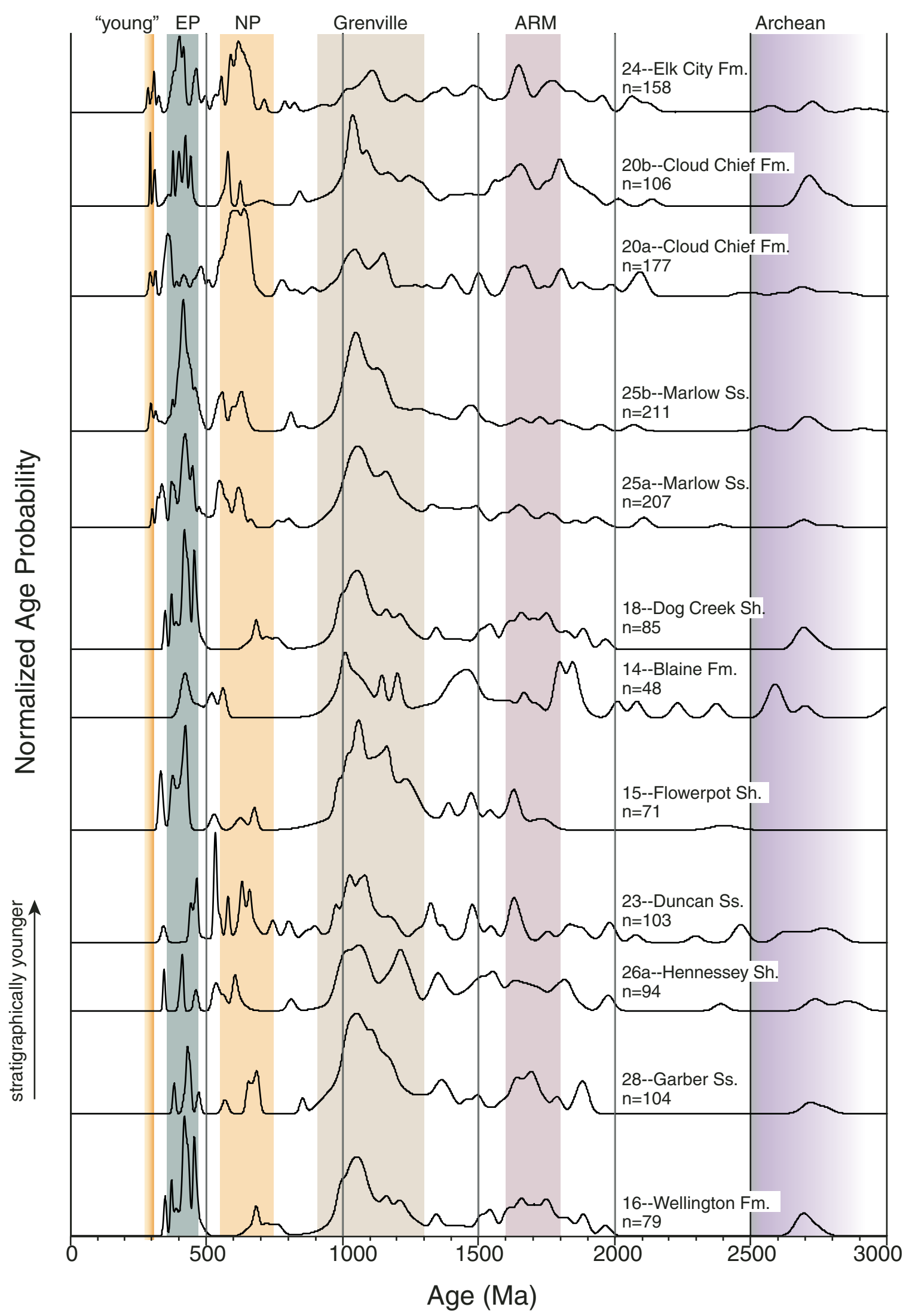

Figure 7. Relative probability plots of detrital-zircon data for samples from Oklahoma outcrop sampling. Age labels at top refer to age groupings discussed in text. Fm-Formation; Ss—Sandstone; Sh-Shale; EP-early Paleozoic; NPNeoproterozoic; ARM-Ancestral Rocky Mountains. 

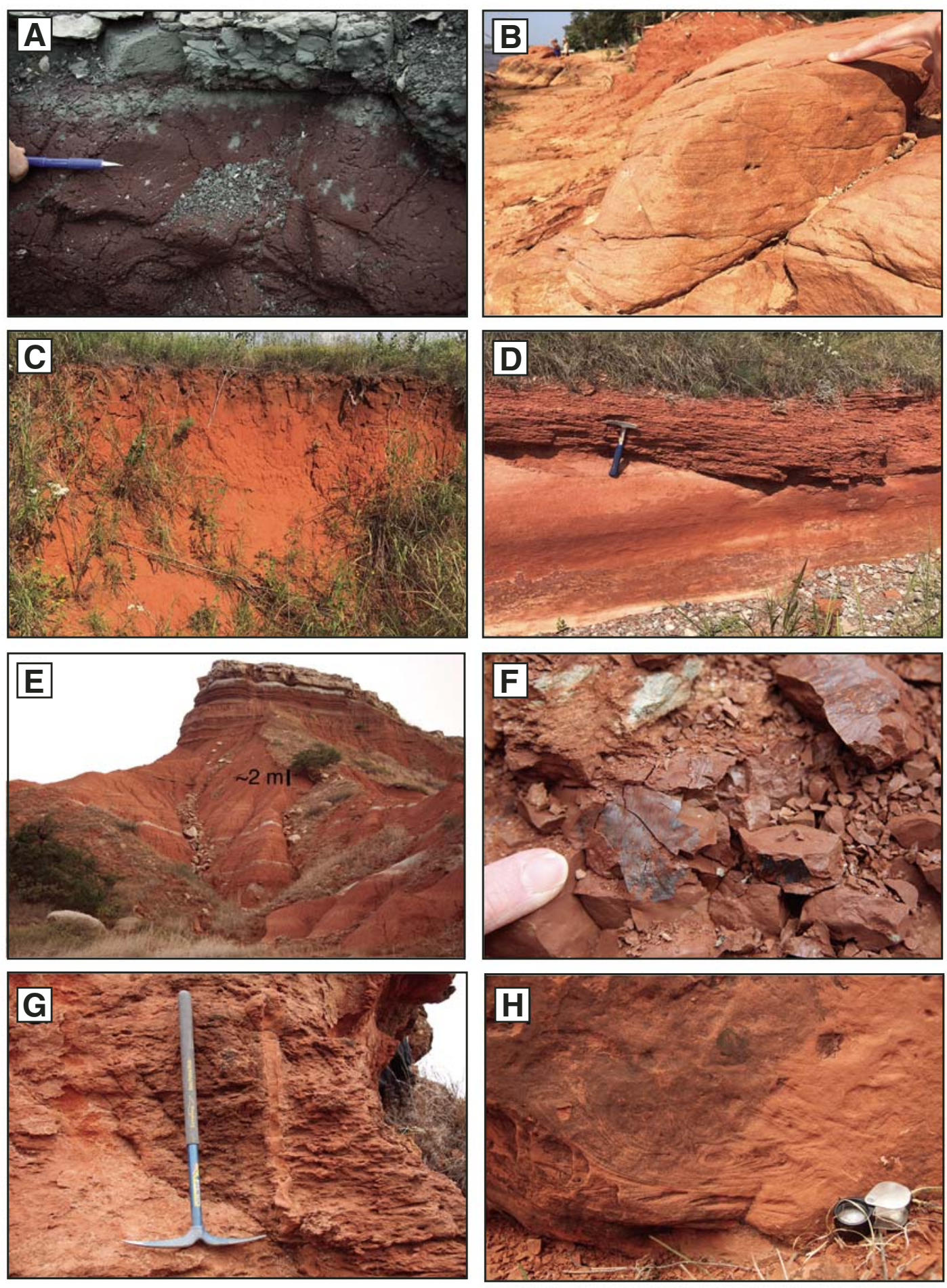

Figure 8. (A) Midco Member of Wellington Formation (Kay County quarry, Oklahoma), showing massive mudstone in an inferred loessitic paleosol. (B) Planar-laminated fine-grained sandstone of Garber Sandstone, Lake Thunderbird, Oklahoma. (C) Massive mudstone of Hennessey Shale exposed in an 2-m-thick road-cut exposure east of Blanchard, Oklahoma. (D) Duncan Sandstone northeast of Chickasha, Oklahoma. Lower unit consists of massive to faintly horizontally laminated, very fine sandstone; this is erosively truncated by a mud-clast conglomerate exhibiting low-angle lateral accretion bedding. (E) Flowerpot Shale capped by mudstone and gypsum of Blaine Formation at Lone Mountain (northwestern Oklahoma). Flowerpot Shale consists predominantly of massive mudstone-siltstone, with multiple horizons exhibiting evidence of pedogenesis. (F) Dog Creek Shale near Greenfield, Oklahoma, showing massive mudstone with slickensided peds along randomly oriented fracture surfaces within an inferred paleosol. (G) Marlow Sandstone near Greenfield, Oklahoma. This view shows fine-grained sandstone with disrupted planar stratification and an inferred lungfish burrow. (H) Soft-sediment deformation in a fine-grained sandstone of the Cloud Chief Formation just west of Clinton, Oklahoma. 
The Garber Sandstone sample contains a majority of zircon with ages of 1300-900 Ma (51\%; Table 2; Fig. 7). The sample also contains abundant 1800-1600 Ma zircon (15\%) and relatively few grains with 485-300 Ma and 740-560 Ma (6\% of each) ages. There are no Permian-age grains.

\section{Sample 26a-Hennessey Shale (Cisuralian, Oklahoma)}

The Hennessey Shale sample, collected from a quarry outcrop, consists of red-brown massive mudstone to orange-red siltstone in beds up to $2 \mathrm{~m}$ thick. These weather in a blocky manner, which is the most common outcrop expression of the Hennessy Shale across central Oklahoma (Fig. 8C). One $\sim 1.5 \mathrm{~m}$ interval of the quarry face near the sampled locality includes mudstone exhibiting lateral-accretion surfaces, which is inferred to record ultimate deposition in a point bar of a fluvial system composed entirely of siltstone and mudstone. The predominance of the fine grain size, the nearly ubiquitous massive character, the blocky fabric (locally reminiscent of Pleistocene loess, or pedogenically modified loess), and near absence of erosively based channels (sandstone or otherwise) suggest sediment transport predominantly by eolian means and thus a loess interpretation. No facies studies exist of the Hennessey Shale, and the only mention of its depositional origin occurs in a report on the Central Oklahoma aquifer, which refers (without documentation) to "marginalmarine and fluvial environments" for the Hennessey Shale and associated Permian units (Breit et al., 1990).

The Hennessey Shale sample consists primarily of zircon with ages of 1300-900 Ma (39\%), but also abundant zircon with ages of 1800-1600 Ma (14\%; Table 2; Fig. 7). There are relatively few grains of Paleozoic or Neoproterozoic age (Table 2); there are no Permian-age grains.

\section{Sample 23-Duncan Sandstone (Guadalupian, Oklahoma)}

The Duncan Sandstone sample, collected from a road cut, consists of red-orange, very fine- to fine-grained, friable quartzose sandstone that is massive to very thinly bedded. Units commonly exhibit pin-stripe laminae that appear inversely graded; locally, cross-stratification occurs in sets up to $3 \mathrm{~m}$ thick. In some exposures, mud-clast conglomerate occurs in erosively based, lenticular beds up to $0.7 \mathrm{~m}$ thick; rare climbing-ripple cross-laminae occur in sandstone units. Previous work on the Duncan Sandstone suggested fluvio-deltaic deposition, based on inferred interfingering of the sand-rich Duncan Sandstone with distal "basinal prodeltaic" shale (e.g., Fay, 1964; Self, 1966; Johnson, 1967). More recently, Foster et al. (2014) questioned this correlation and furthermore inferred a loess origin for the "basinal prodeltaic" shales. On the basis of the consistent very fine sand size and presence of inversely graded laminae (translatent stratification), we infer a predominantly eolian (sand sheet) origin for the Duncan Sandstone, with evidence for local fluvial reworking (subordinate mud-clast conglomerate) in wadi-type ephemeral channels.

The Duncan Sandstone sample contains numerous 1300$900 \mathrm{Ma}$ zircon grains (29\%), but also 740-560 Ma and 25001800 Ma zircon ages (13\% each; Table 2). There are relatively few Paleozoic grains or grains with 1800-1600 Ma ages (Table 2, Fig. 7). There are no Permian-age grains.

\section{Sample 15-Flowerpot Shale (Guadalupian, Oklahoma)}

The Flowerpot Shale sample was collected from outcrop. This formation consists predominantly of massive red-brown siltstone with discrete horizons marked by randomly fractured clayey siltstone that locally exhibits nodules of gypsum, or downwardly bifurcating root traces (Fig. 8E). Very fine-grained sandstone in 1-2-m-thick massive beds occurs rarely. This unit is interpreted as paleo-loess with common paleosols and minor eolian sand sheets (Sweet et al., 2013).

The Flowerpot Shale sample contains a majority of 1300$900 \mathrm{Ma}$ zircon (59\%), but also with abundant 485-300 Ma zircon $(14 \%$, with an age peak at $420 \mathrm{Ma})$ and relatively few Neoproterozoic grains or grains with ages of 1800-1600 Ma (7\%; Table 2; Fig. 7). There are no Permian-age grains.

\section{Sample 14-Blaine Formation (Guadalupian, Oklahoma)}

The Blaine Formation consists of several named dolostone ( $5 \mathrm{~cm}$ to $1 \mathrm{~m}$ thick) and gypsum (1-7 $\mathrm{m}$ thick) units intercalated with (volumetrically predominant) red-brown massive mudstone to siltstone and rare fissile shale (Fig. 8E). The evaporite units of the Blaine Formation, and by association the intervening siliciclastic facies, have commonly been interpreted to represent sabkha-type environments and thus deposition in marginal-marine environments (e.g., Fay, 1962; Johnson, 1967, 1988); Fay (1964) buttressed this interpretation with reports of local rare (inferred marine) invertebrates in regions south of our study area. However, Sweet et al. (2013) documented siliciclastic facies analogous to those of the Flowerpot Formation and inferred a predominantly eolian origin for the siliciclastic units. Additionally, correlative units in Kansas have been reinterpreted as the products of saline lacustrine systems (Benison and Goldstein, 2001).

The Blaine Formation has a unique detrital-zircon signature compared to underlying and overlying intervals. There is a relatively low percentage of zircon grains with ages 1300-900 Ma and no Neoproterozoic grains (Table 2; Fig. 7). The sample contains 6\% Paleozoic zircon grains and $19 \%$ early Paleoproterozoic (2500-1800 Ma) grains.

\section{Sample 18-Dog Creek Shale (Guadalupian, Oklahoma)}

The Dog Creek Shale sample was collected from outcrop. This unit consists of red-orange, thickly bedded massive siltstone and mudstone with common randomly oriented slickensides concentrated in discrete horizons (Fig. 8F). Auxiliary facies include planar to convolutely laminated red siltstone in thin to medium beds, as well as rare red-orange, very fine-grained, laminated sandstone with rounded grains. This unit is interpreted as recording eolian transport and deposition (as loess and minor sand sheets) in eolian systems and ephemerally wet mud flats, with common pedogenic overprinting (Foster et al., 2014).

The Dog Creek Shale sample contains roughly equal numbers of zircon grains within the different age groupings (Table 
2; Fig. 7). There are slightly more grains with ages of 1300 $900 \mathrm{Ma}(20 \%)$, but $13 \%$ of grains that are of Paleozoic and Neoproterozoic age, $15 \%$ with ages of $1800-1600 \mathrm{Ma}$, and $12 \%$ ages of 2500-1800 Ma. There is one grain of Permian age.

\section{Samples 25a and 25b-Marlow Sandstone (Guadalupian, Oklahoma)}

The Marlow Sandstone sample, collected from outcrop, consists of friable, red-brown, very fine- to fine-grained silty sandstone in beds up to $2 \mathrm{~m}$ thick, interbedded with red-brown siltstone to mudstone. Local medium-grained, well-rounded, and frosted sand grains are mixed within the finer-grained sandstone. Internally, beds exhibit a faintly laminated structure, but laminae are highly disrupted, with common bulbous structures lending an overall mottled appearance, as well as vertical burrows (up to $1 \mathrm{~m}$ long, 5-20 cm diameter; Fig. 8G). The Marlow Formation in the greater region contains three discrete dolomite beds $<1-$ $6 \mathrm{~cm}$ thick, with crinkly laminations; it is gypsiferous in northern and northwestern exposures (Fay, 1964). The fine grain size, with frosted and rounded grains and tabular beds, is consistent with eolian transport, but the burrows appear to record lungfish estivation (cf. Giles et al., 2013), and the highly disrupted and mottled character is interpreted to reflect pervasive bioturbation in environments that were likely seasonally wet.

Fay (1964) inferred a fluvio-deltaic to marine interpretation for the Marlow Sandstone, owing in part to the associated chemical facies, and fossils that include an inferred brackish water clam. We favor eolian transport of clastics into ephemeral ponds or coastal mudplains (cf. Giles et al., 2013; Voigt et al., 2013) for the depositional environment responsible for the sampled unit.

The two Marlow Sandstone samples have similar zircon age distributions. Both contain over $40 \%$ of grains with ages of 1300 $900 \mathrm{Ma}$ (Table 2; Fig. 7) and 18\%-19\% zircon with 485-300 Ma ages (both with an age peak of ca. $415 \mathrm{Ma}$ ). Both samples contain $<10 \%$ Neoproterozoic grains or grains with 1800-1600 Ma ages (Table 2; Fig. 7). There is one Permian-age grain between the two samples.

\section{Samples 20a and 20b-Cloud Chief Formation (Lopingian, Oklahoma)}

The two samples of the Cloud Chief Formation, collected from outcrop, consist predominantly of red-orange to red-brown siltstone that is internally massive and thickly to very thickly bedded, with local blocky fracturing and randomly oriented slickensides (Gergurich, 2015). Although the predominant lithofacies is massive siltstone, beds $(<10-35 \mathrm{~cm}$ thick) of very fine-grained sandstone exhibiting soft-sediment deformation (Fig. $8 \mathrm{H}$ ) or ripple cross-stratification or small-scale cross-stratification also occur. The massive and fractured to slickensided siltstone is interpreted as loess and pedogenically modified loess, respectively, whereas the ripple cross-stratification and soft-sediment deformation indicate the local influence of water (Gergurich, 2015). Accordingly, this siltstone sample is interpreted to reflect predominantly eolian transport, and the sand sample is interpreted as a fluvial deposit representing ephemeral fluvial channels. Recent work on the more broadly distributed Cloud Chief Formation includes volumetrically minor evaporite and carbonate facies in addition to the fine-grained siliciclastic components, and it has been interpreted as a sabkha environment for the chemical facies, and fluvial (terminal splay) and mud-flat environments for the siliciclastic facies (Brillo, 2015).

The Cloud Chief Formation sandstone and siltstone samples exhibit different distributions of detrital-zircon ages. The sandstone sample contains almost equal numbers of grains with ages of 1300-900 Ma and Neoproterozoic grains (Table 2; Fig. 7 ). The sandstone sample also contains $\sim 10 \%$ Paleozoic grains and grains with ages ranging from 1800 to 1600 Ma ages. The siltstone sample, however, consists of more grains with 1300900 Ma ages (37\%; Table 2; Fig. 7) and relatively few grains with Neoproterozoic ages. The siltstone sample also contains 9\% Paleozoic grains and grains with 1800-1600 Ma ages. Each sample contains one grain of Permian age.

\section{Sample 24-Elk City Sandstone (Lopingian, Oklahoma)}

The Elk City Sandstone sample, collected from outcrop, consists of friable, fine-grained, orange-brown sandstone in beds 1-4 m thick, with local siltstone interbeds. Internally, beds exhibit thin horizontal stratification, or trough cross-stratification in sets 1-4 $\mathrm{m}$ thick, and local vertical burrows as appear in the Marlow Formation (interpreted as lungfish burrows). Although Fay and Hart (1978) suggested a marine origin owing to the burrows and inferred "submarine cross bedding," we suggest that the consistently fine grain size and large-amplitude cross-stratification are more consistent with eolian deposition, although the lungfish burrows signal ephemeral wetting.

The Elk City Sandstone sample contains roughly equal numbers of zircon grains within the different age ranges (Table 2; Fig. 7), with slightly more grains within the 1300-900 Ma range. The sample contains two grains of Permian age.

\section{Summary of Vertical and Spatial Changes in Detrital-Zircon Geochronology}

All samples analyzed in both subsurface (RKB core of Kansas) and surface (Oklahoma outcrop) contain similar populations of detrital-zircon ages, but relative percentages of age groupings vary. For example, the percentages of Paleozoic (485$300 \mathrm{Ma}$ ) and Mesoproterozoic (1300-900 Ma) zircon increase nonuniformly up section through Permian strata of the RKB core and outcrops of western Oklahoma. The highest percentages of Paleozoic (485-300 Ma) zircon occur in samples that are latest Cisuralian to earliest Guadalupian in age within the RKB core (Harper Sandstone-lower Nippewalla Group); these are most abundant (25\% of all zircon grains) within the eolian Whitehorse Formation (mid-Guadalupian). In western Oklahoma, Paleozoic (485-300 Ma) grains increase in abundance to a maximum within the roughly coeval Marlow Formation (18\%-19\% in two samples), but overall the percentage of Paleozoic grains 
SPE540-28 1st pgs page 18

is 5\%-10\% lower in Guadalupian strata of Oklahoma. Likewise, the Mesoproterozoic (1300-900 Ma) zircon grains increase in abundance through Guadalupian strata from $\sim 30 \%$ to over $50 \%$ within the Flowerpot Shale. In western Oklahoma, Mesoproterozoic (1300-900 Ma) zircon grains are more abundant (up to $51 \%$ ) in lower (Cisuralian) strata, and they are also abundant in Guadalupian strata, with a maximum of $59 \%$ within the Flowerpot Shale. Abundance of Mesoproterozoic grains decreases within the upper Nippewalla and El Reno Groups (Kansas and Oklahoma, respectively), but in the Lopingian strata of western Oklahoma, the relative number of Mesoproterozoic (1300$900 \mathrm{Ma}$ ) zircon grains increases, but without a similar relative increase in Paleozoic grains.

Within the oldest (Cisuralian) strata of the RKB core, the abundance of Neoproterozoic (740-560 Ma) grains is relatively high, ranging from $14 \%$ to $18 \%$ within the Council Grove Group, and up to $21 \%$ within the Chase Group. Within the Nippewalla Group, the percentage of Neoproterozoic (740-560 Ma) zircon grains is consistently less than $10 \%$, again reflecting a temporal change within latest Cisuralianearliest Guadalupian time. Within Oklahoma outcrops, the Wellington and Garber-Hennessey samples (upper Cisuralianlowermost Guadalupian) exhibit low abundances (4\%-6\%) of Neoproterozoic zircon grains, and percentages of grain with these ages remain consistently low through the Guadalupian (except for two samples $>10 \%$ ). The Lopingian samples within Oklahoma contain higher percentages of Neoproterozoic grain $(14 \%-23 \%)$.

Paleoproterozoic grains (1800-1600 Ma) vary from $10 \%$ to $16 \%$ of detrital-zircon grains within Cisuralian strata of the RKB core; in the oldest (upper Cisuralian) samples within Oklahoma, Paleoproterozoic (1800-1600 Ma) grains vary in abundance from $14 \%$ to $18 \%$. The RKB core contains fewer Paleoproterozoic zircon grains in upper Nippewalla Group samples $(<10 \%)$; in the Oklahoma samples, the El Reno Group samples vary between $7 \%$ and $15 \%$. The youngest samples in both sections exhibit increases in abundance of these grains.

There are a few other subtle changes in relative changes in abundances of other populations. Young (Permian; younger than $300 \mathrm{Ma}$ ) zircon grains are absent in older samples from Oklahoma, but compositions reach a few percent in samples throughout the RKB core. Early Paleoproterozoic (2500$1800 \mathrm{Ma})$ grains are abundant (9\%-12\%) in Cisuralian samples of the RKB core, but they are less abundant $(3 \%-7 \%)$ in Guadalupian samples. However, in Oklahoma, abundances of Paleoproterozoic (2500-1800 Ma) zircon grains are more variable, ranging from $1 \%$ to $20 \%$, but they are overall more abundant in Guadalupian (El Reno Group) samples and increase to $>10 \%$ in Lopingian samples. Archean (older than $2500 \mathrm{Ma}$ ) zircon grains range from $2 \%$ to $8 \%$ within the RKB core, but they do not show any obvious trend; similar-age zircon grains may be slightly more abundant in some Oklahoma samples $(0 \%-11 \%)$, but again they do not show a consistent temporal trend in abundance.

\section{POTENTIAL SOURCES FOR DETRITAL-ZIRCON AGE POPULATIONS}

We briefly summarize potential sources for the age groupings noted in Table 2 and discussed above. These age groupings are keyed to known basement provinces and terranes of North America and marginal regions (Fig. 9), and to results of other detrital-zircon provenance studies of Paleozoic strata from North America.

\section{Archean (Older Than 2500 Ma)}

Archean (older than $2500 \mathrm{Ma}$ ) zircon was most likely sourced from the Superior Province $(3.0 \mathrm{Ga}, 2.7-2.5 \mathrm{Ga})$ in the core of the Laurentian craton (Hoffman, 1989; Van Schmus et al., 1996). The Superior-Wyoming craton (2.8-2.5 Ga) was covered during the late Paleozoic (McKee and Oriel, 1967), so this might imply recycling of these grains from old zircon within lower to mid-Paleozoic strata (Gehrels et al., 2011) draping or adjacent to regional basement uplifts. Grains of Archean age have also been documented from Pennsylvanian strata in the Marathon-Ouachita system (Sharrah, 2006; Gleason et al., 2007), and coeval Permian strata of the Grand Canyon (e.g., Gehrels et al., 2011), and Delaware Basin (Soreghan and Soreghan, 2013).

\section{Paleoproterozoic (2500-1800 Ma)}

Paleoproterozoic detrital zircon might have been derived from many possible source terranes. In Paleozoic Laurentia, 1900-1800 Ma zircon was likely sourced originally from the Trans-Hudson and Penokean orogen, which connected the Wyoming and Superior Provinces (Fig. 9; Hoffman, 1989). The eastern Mojave Province contains 2300-1600 Ma zircon, although the main age range is from 2200 to 2000 Ma (Soreghan et al., 2002; Gleason et al., 2007). Gondwanan crustal terranes from Amazonian or West African cratons contain grains of this age as well (Weber et al., 2006). For example, detrital zircon from Silurian-Devonian strata of the Suwanee terrane in Florida (likely accreted and uplifted during the Alleghanian orogeny) has a bimodal age population at 2282-1967 Ma and 637-515 Ma that strongly suggests derivation from Africa or South America (Mueller et al., 1994; Becker, 2005).

\section{Late Paleoproterozoic (1800-1600 Ma)}

Late Paleoproterozoic (1800-1600 Ma) zircon has long been associated with the Yavapai (ca. 1.8-1.7 Ga)-Mazatzal (a. 1.7$1.6 \mathrm{Ga}$ ) terrane and associated Central Plains orogen that constitutes much of the (metasedimentary and metavolcanic) basement of southwestern North America (Fig. 9; Van Schmus et al., 1993, 1996; Karlstrom et al., 2003). Basement of this age was exposed in uplifts of the Ancestral Rocky Mountains during Pennsylvanian-Early Permian time, and grains of these ages are documented in Pennsylvanian-Lower Permian strata of the western 


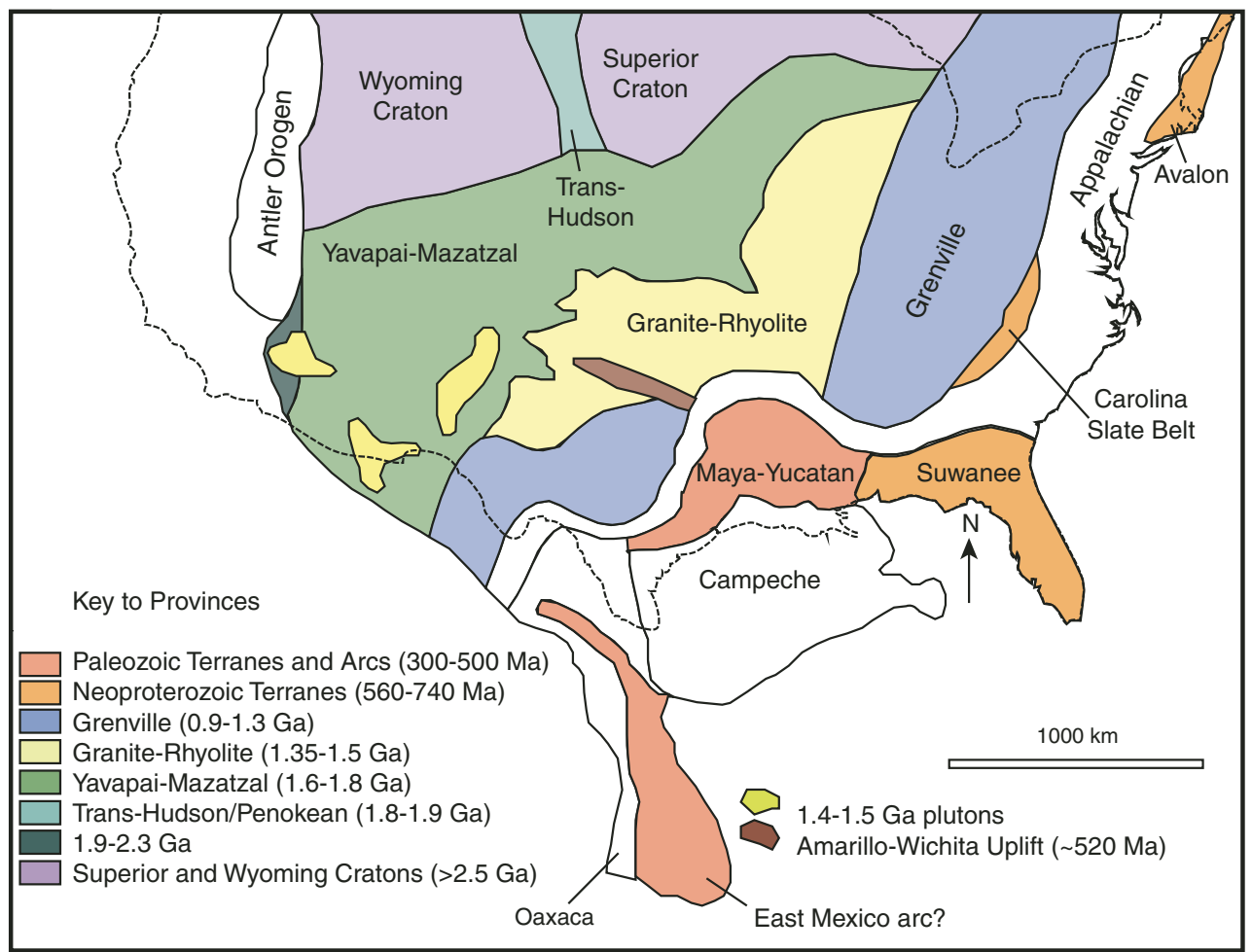

Figure 9. Primary basement provinces for North America. Note exact locations and basement ages for peri-Gondwana Mexican terranes (e.g., Coahuila, Yucatan-Maya terranes) are generalized because interpretations vary for exact placement of these sources. Figure is modified from Soreghan et al. (2002).

United States (M.J. Soreghan et al., 2002, 2008; Soreghan et al., 2007; Dickinson and Gehrels, 2003; Gehrels et al., 2011; Giles et al., 2013; Soreghan and Soreghan, 2013; Sweet et al., 2013; Link et al., 2014; Lawton et al., 2015). Detrital-zircon grains with these ages have also been documented from Pennsylvanian strata of the Marathon and Ouachita orogens (e.g., Sharrah, 2006; Gleason et al., 2007).

\section{Mesoproterozoic (1300-900 Ma)}

Mesoproterozoic (1300-900 Ma) zircon represents a welldocumented population from the Grenville orogen, which occupies parts of southern and eastern North America, and parts of Mexico and regions of northwestern Gondwana (South America; Hoffman, 1989; Fig. 9). In North America, Grenville-age rocks primarily occupy the Laurentian flank of the Appalachians and southeastern Laurentia, as well as parts of Texas and the Oaxacan terrane in Mexico (Bream, 2002; Dickinson and Gehrels, 2003; Becker, 2005; Weber et al., 2006; Martens et al., 2010). Detritalzircon grains of Grenville age are also common in Neoproterozoic to Lower Paleozoic sedimentary and metasedimentary strata incorporated into thrust belts associated with the Appalachian orogen, which may have shed recycled zircon westward into late Paleozoic basins (McLennan, et al., 2001; Eriksson et al., 2004; Park et al., 2010). Additionally, Grenville-age zircon could be sourced from deformed and recycled Paleozoic strata uplifted during the Ouachita orogeny to the west and south of the Appalachians (Dickinson and Gehrels, 2003; Sharrah, 2006). One pos- sible source distinction is that Oaxacan (Gondwanan) Grenvillian basement to the south has younger zircon peaks (ca. $990 \mathrm{Ma}$ ) than Laurentian Grenville basement (1225-1020 Ma) to the east, although without a large sample population of Grenville grains, it can be difficult to make such a distinction (Dickinson and Gehrels, 2003; Gleason et al., 2007). Grenville-age zircon typically forms prominent populations in North American sandstone ranging in age from Neoproterozoic through Mesozoic (e.g., Rainbird et al., 1992, 1997, 2012; Dickinson and Gehrels, 2003; Moecher and Samson, 2006; Sharrah, 2006; Gleason et al., 2007; Dickinson, 2008; Dickinson et al., 2010; Gehrels et al., 2011; Soreghan and Soreghan, 2013; Gehrels and Pecha, 2014), such that they apparently reflect extreme "zircon fertility" (Moecher and Samson, 2006).

\section{Neoproterozoic (740-560 Ma)}

Neoproterozoic zircon typically is not found in Laurentian (primary) basement terranes. The Mount Rogers volcanics (Virginia) and the Robertson River pluton (North Carolina) both encompass ages of 760-680 Ma, but both sources cover a small area and are overlain by Paleozoic strata, making them unlikely source terranes (Rankin et al., 1989; Becker, 2005; Sharrah, 2006). There are also some 620-530 Ma Iapetan synrift igneous rocks in the Appalachians from Newfoundland to North Carolina (Becker, 2005).

Neoproterozoic (740-560 Ma) zircon is documented in several "peri-Gondwanan" terranes entrapped within the 
Gondwanan-Laurentian suture (e.g., Murphy et al., 2004). Within the Appalachian region, these terranes include: the Avalon (Northern Appalachians), Carolina (Southern Appalachians), and Suwanee (Florida subsurface), which were eroded as part of the interior Appalachian orogen during the late Paleozoic (e.g., Opdyke et al., 1987; Mueller et al., 1994; Nance and Thompson, 1996; Dickinson and Gehrels, 2003, and references therein; Murphy et al., 2004; Sharrah, 2006; Martens et al., 2010; Pollock et al., 2012; Thompson et al., 2012), or recycled from rift-related strata of Neoproterozoic basins entrained in the Appalachian orogeny (Thomas et al., 2004).

Peri-Gondwanan terranes with Neoproterozoic crustal elements were also located south, southeast, and southwest of the study area (Fig. 1), ultimately accreted to and now present in Mexico and Central America. Interpretations vary for positions of these peri-Gondwanan Mexican terranes (e.g., Dickinson and Lawton, 2001; Murphy et al., 2004; Keppie et al., 2004; Vega-Granillo et al., 2008; Martens et al., 2010); however, all were ultimately involved in the Pangean orogenic zone and were thus capable of supplying zircon toward and into the Ouachita-Marathon system. For example, the Coahuila and Yucatan-Maya terranes of Mexico were uplifted and shedding sediment by Permian time (Sacks and Secor, 1990; Dickinson and Lawton, 2001; Gillis et al., 2005; Poole et al., 2005). The Yucatan-Maya terrane includes Permian-Pennsylvanian strata with detrital-zircon ages that include a 650-500 Ma population (Weber et al., 2006, 2008; Martens et al., 2010). Sharrah (2006) documented Neoproterozoic zircon in Lower Pennsylvanian deep-water strata of the Ouachita foreland (Arkoma Basin) and combined these data with paleocurrent results to suggest a Yucatan (Maya block) source for these grains. Soreghan and Soreghan (2013) called upon these peri-Gondwanan terranes as sources for Neoproterozoic grains within strata of the Permian Midland Basin.

\section{Paleozoic (485-300 Ma)}

Paleozoic detrital zircon could reflect several source terranes, although most are related to the Appalachian orogen, Ouachita orogen, Maya block, and Oaxaca terrane of Mexico (Fig. 9; Soreghan et al., 2002; Dickinson and Gehrels, 2003; Becker, 2005; Weber et al., 2006; Gleason et al., 2007; Soreghan et al., 2007; Martens et al., 2010; Gehrels et al., 2011; Soreghan and Soreghan, 2013). In the Appalachians, distinct pulses of magmatism, tectonism, and uplift during the Alleghanian, Acadian, and Taconic orogenies provided Paleozoic igneous and metamorphic rocks. Various dispersal pathways have been hypothesized for delivery of sediment from the Appalachian highlands to the south and west, including transportation to the Ouachitas through the Illinois Basin (Thomas, 2011; Sharrah, 2006), sediment recycling and transport along the Ouachita suture (Gleason et al., 2007), and large-scale river systems transporting sediment across the Laurentian continent (Dickinson and Gehrels, 2003; Gehrels et al., 2011).
Similar Paleozoic zircon could also have been sourced from peri-Gondwanan terranes of Mexico and South America, including the Maya block, the Acatlán complex of central and southern Mexico, and the Las Delicias arc of the Coahuila terrane, Mexico (Yañez et al., 1991; Soreghan et al., 2002; Dickinson and Gehrels, 2003; Sharrah, 2006; Weber et al., 2006; Gleason et al., 2007; Soreghan et al., 2007; Martens et al., 2010). Large 420-400 Ma and $320 \mathrm{Ma}$ zircon populations are ubiquitous in granitoids of the Maya block and the Las Delicias arc, respectively (Yañez et al., 1991; Soreghan et al., 2002; Dickinson and Gehrels, 2003; Sharrah, 2006; Weber et al., 2006; Gleason et al., 2007; Soreghan et al., 2007; Martens et al., 2010).

\section{DISCUSSION}

\section{Permian Depositional Systems of the Midcontinent}

Permian strata crop out across western Oklahoma and Kansas, but very low dips $\left(1^{\circ}-2^{\circ}\right)$ combined with low-relief have greatly compromised outcrop studies. Moreover, with the exception of the RKB core, few cores have been taken in the Permian section of the greater Anadarko Basin region owing to the limited economic significance of Permian strata. The presence of evaporite/carbonate strata, presumed proximal-distal grainsize trends, and tenuous correlations to unequivocally marine units of the Permian basin caused many previous authors (see above) to assign depositional interpretations of fluvio-deltaic or tidal/restricted marine settings. In the RKB core, however, of the $540 \mathrm{~m}$ of Permian section penetrated, $77 \%$ consists of mudstonesiltstone, $11 \%$ consists of very fine- to fine-grained sandstone, and $12 \%$ consists of chemical (limestone, halite, gypsum/anhydrite) strata. The scarcity of fluvial channels is problematic in terms of a sediment-delivery mechanism capable of transporting these enormous volumes of siliciclastic material to the midcontinent; furthermore, the vast distances to unequivocally Permian shorelines (Permian basin of Texas) cast doubt on the efficacy of tidal currents for enabling such transport. Finally, characteristic features of tidal systems, such as tidal bedding, do not occur.

More recently, several of these units (e.g., Wellington Formation, Flowerpot Shale, Dog Creek Shale, Cloud Chief Formation, Rush Springs Sandstone, parts of the Council Grove Group) have undergone detailed facies analysis, resulting in reinterpretations that emphasize probable eolian transport for the vast volume of the uniformly fine-grained siliciclastic material composing these units (e.g., Dubois et al., 2012; Poland and Simms, 2012; Giles et al., 2013; Sweet et al., 2013; Foster et al., 2014; Brillo, 2015; Gergurich, 2015). Even for the few instances in which unequivocal signs of water transport occur, such as mudclast conglomerate and lateral-accretion bedding, the uniformly fine grain size and auxiliary signs of eolian influences suggest water overprinting of sediment that ultimately reached the midcontinent via wind. Analogously, many of the evaporitic units have been reinterpreted as the deposits of saline lacustrine, rather than marine systems (Benison and Goldstein, 2000; Benison et 
al., 2013). Accordingly, the emerging paleogeographic picture for this region of the midcontinent during the Permian is one of a widespread arid landscape, with influx of siliciclastic material delivered predominantly via eolian transport into a sink that was able to effectively capture this material, in part owing to ephemeral wetting across a broad, continuously subsiding region of mud flats, loess fields, and sand dunes and sheets, with limited influence of ephemeral wadi-type fluvial systems. The spatial limitations of the core and outcrop data make it difficult to demonstrate if this was a truly endorheic system, but the balance of evidence argues strongly against the presence of large, throughgoing fluvial systems in this region of the southern midcontinent through Permian time.

\section{Permian Provenance Shift Reflecting Evolving Orogenesis and Atmospheric Circulation}

The southern midcontinent preserves arguably the most complete Permian record of the Western Hemisphere, owing to continual epeirogenic subsidence of the greater Anadarko Basin region that extended nearly to the end-Permian (Soreghan et al., 2012). Hence, although provenance signatures within this interval exhibit similarities to those documented for other Permian strata of the western United States (e.g., M. Soreghan et al., 2002; Soreghan et al., 2007; Gehrels et al., 2011; Lawton et al., 2015), the unprecedented length and richness of the record document discrete shifts in sources through time. One potential caveat to the interpretation of provenance from units of varying grain size concerns whether or not transport-related sorting of zircons produced provenance bias. This effect has been tested preliminarily in fluvial systems (e.g., Lawrence et al. 2011; Yang et al., 2012), but it remains poorly understood for eolian systems. M.J. Soreghan et al. (2008) documented grain-size variations in detrital zircon between a Permian loessite and overlying paleosol, which were interpreted as changes in wind strength, because there were similar $\mathrm{U}-\mathrm{Pb}$ age ranges present in both units, even though the zircons were of different grain size.

The first-order shift that occurred with time from the Cisuralian to the Guadalupian includes: (1) reduction of YavapaiMazatzal and (to a lesser degree) Neoproterozoic sources, and (2) increases in Grenvillian and Paleozoic sources. Lower Permian (Cisuralian) units exhibit nearly subequal proportions of Grenvillian, Neoproterozoic, and Yavapai-Mazatzal grains, whereas Grenvillian (primarily) and early Paleozoic (secondarily) grains overwhelmingly predominate in Guadalupian and Lopingian strata. We interpret this shift to reflect temporal evolution in orogenesis accompanying central Pangean assembly and offshoots, such as the Ancestral Rocky Mountains system, augmented by strengthening of megamonsoonal circulation, which is well documented for western equatorial Pangea (Fig. 10).

The presence of Yavapai-Mazatzal zircon is reasonable and expected for Cisuralian samples of the western and midcontinent United States, as these appear to reflect proximity to exposed Ancestral Rocky Mountains uplifts and imply a signifi- cant easterly directed contribution of sediment from basementcored orogenic uplifts located west of the study region. These 1800-1600 Ma zircon grains are also abundant in Cisuralian strata west and southwest of the study area (M.J. Soreghan et al., 2002, 2008, 2014; Gehrels et al., 2011), suggesting that fluvial systems emanating from Ancestral Rocky Mountains uplifts dispersed sediments in various directions that were then reworked by eolian processes.

Lower Permian strata within the Northern Appalachian basin contain few to no Neoproterozoic zircon grains (Becker et al., 2006); thus, although the Appalachian orogen provided sediment with a Grenville signature to the Northern Appalachian basin, bypass of the central/northern Appalachian foreland could not have occurred to enable transport across an overfilled basin directly to the midcontinent during the Cisuralian (Fig. 10A). Thus, two alternative scenarios exist: (1) Neoproterozoic grains could have been derived from uplifts within the southeastern part of the Appalachian orogen. The Suwanee terrane, which contains Neoproterozoic crustal elements, is a possible source. This scenario, however, would require the fluvial trunk system to have cut through the thrust belt of the Southern Appalachians to deliver sediment to the southern part of the midcontinent, which would then have been subsequently reworked by eolian processes to the west and northwest. (2) Neoproterozoic zircon within Lower Permian eolian units of western Pangea may have been transported through fluvial systems located significantly south of the midcontinent, ultimately derived from the region behind the Ouachita orogenic front (Fig. 10A). As noted above, the Coahuila and Yucatan (-Maya) terranes were topographically positive regions in Permian time (Sacks and Secor, 1990; Dickinson and Lawton, 2001; Gillis et al., 2005; Poole et al., 2005). The Ouachita/Arkoma Basins were overfilled by Permian time; thus, these potential fluvial systems may have flowed into the midcontinent region (Fig. 10A) via southern transport routes, with sediment then reworked by eolian processes (Soreghan and Soreghan, 2013).

In summary, during the Early Permian, erosion of active orogens west and southeast of the study region delivered the majority of clastic sediment to the midcontinent region, with Ancestral Rocky Mountains contributions predominating west, and Grenville and, to a lesser degree, Neoproterozoic populations predominating to the southeast. However, diminishment of Yavapai-Mazatzal sources with time through the Permian is interpreted to record the loss of these sources with increasing burial of the Ancestral Rocky Mountains uplifts. Orogenesis in the core Ancestral Rocky Mountains uplifts, which had been denuded to crystalline basement, peaked in Pennsylvanian time (Kluth, 1986; Dickinson and Lawton, 2003), and abundant sediment was shed from the exposed basement to form sediment aprons directly mantling these uplifts. Much of this firstcycle sediment was trapped proximal to the uplifts, but some apparently made it farther east into eolian-dominated environments via monsoonal westerly winds during the Permian (e.g., M.J. Soreghan et al., 2002, 2008, 2014; Lawton et al., 2015). 


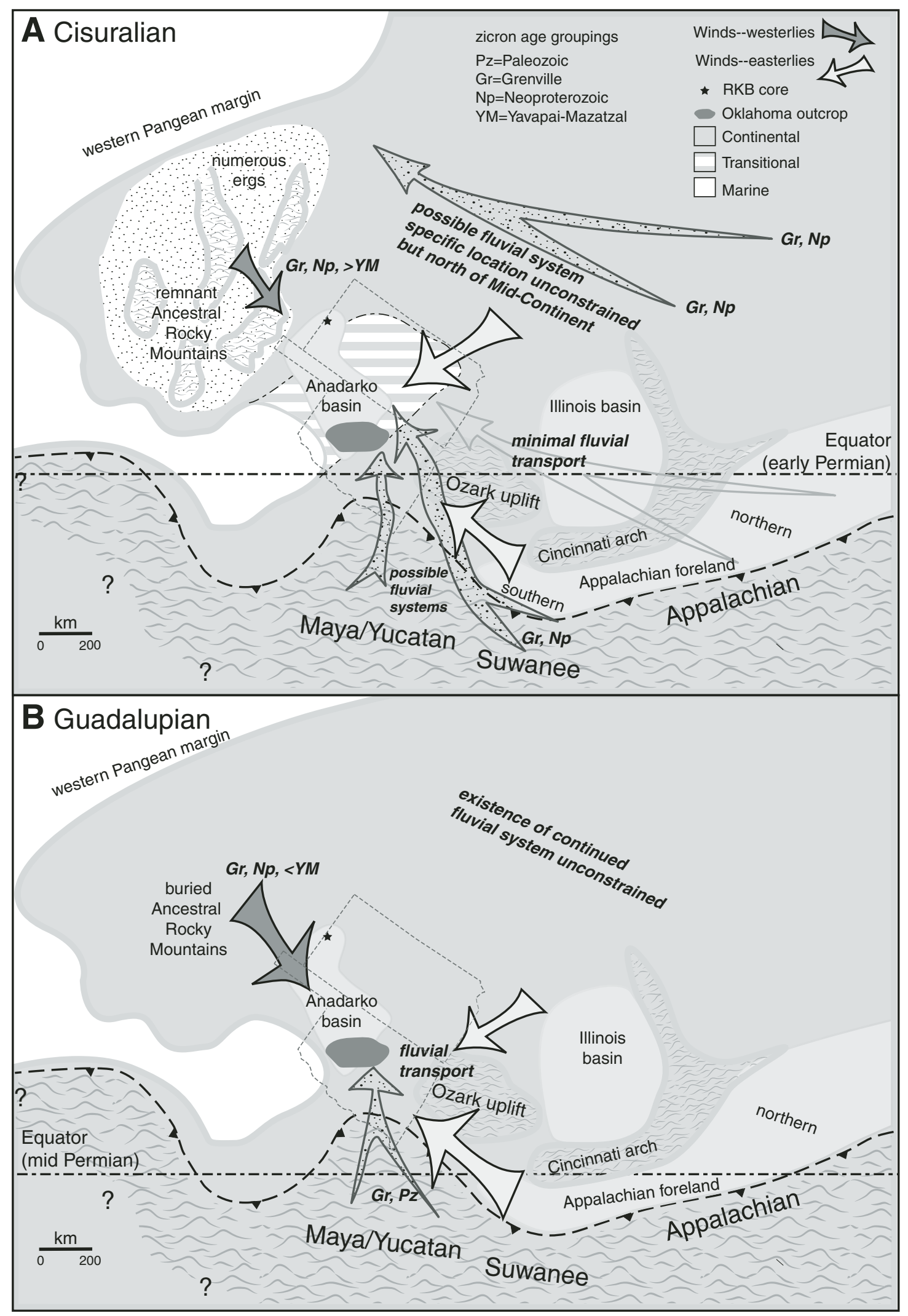

Figure 10. Interpretive diagram showing paleogeographic elements and inferred transport pathways for clastic sediment into midcontinent and Anadarko Basin during Permian time: (A) Early Permian and (B) Middle Permian. Relative sizes of time-averaged wind direction arrows reflect inferred importance and were derived from general climate models, including Heavens et al. (2015). Significance and interpreted sources of age groupings are discussed in text. 
Although Ancestral Rocky Mountains uplifts have commonly been depicted as persisting as erosional remnants that shed sediment continually into Mesozoic time, stratal relations around at least two of the major Ancestral Rocky Mountains uplifts with the largest fault displacements (the Wichita-Anadarko system, and the Uncompahgre-Paradox system) were buried by at least $1 \mathrm{~km}$ of Permian strata (Ham et al., 1964; Cater, 1970; Soreghan et al., 2012), when apparent epeirogenic subsidence affected both the basins and adjacent uplifts. Hence, it appears that the Ancestral Rocky Mountains uplifts ceased to serve as direct first-cycle sediment sources relatively early in Permian time, and the relatively low percentages of 1800-1600 Ma zircon grains in Guadalupian strata of the midcontinent $(<10 \%)$ may reflect recycling of slightly older strata.

The significant increase in the relative proportion of Grenville (1300-900 Ma) and Paleozoic grains (concentrated ca. 420-400 Ma) in Guadalupian strata compared to underlying Cisuralian strata is interpreted to reflect uplift of source terranes lying mostly to the south and southeast of the Ouachita suture. Grenville basement is a potential source now underlying the southern and southeastern United States; Paleozoic grains exhibit a mode at ca. $420 \mathrm{Ma}$, which matches sources emanating from the Yucatan-Maya region and is also recorded in younger Permian strata of the Permian basin (Soreghan and Soreghan, 2013). Thus, this change in provenance from the Cisuralian to Guadalupian may correspond to a major docking of terranes to the south, when rapid uplift and erosion ultimately brought these sediments toward the midcontinent via overfilling of the Arkoma foreland basin and Ouachita systems.

Monsoonal circulation and progressive Permian aridification likely also played significant roles in sediment redistribution of the Permian in the midcontinent, given the importance of eolian systems across this region. The well-known megamonsoonal circulation of Pangea is thought to have begun by the Pennsylvanian-Permian boundary (M. Soreghan et al., 2002; Tabor and Montañez, 2002) and strengthened through the Permian, reaching maximum development in Triassic time (Dubiel et al., 1991; Parrish, 1993). Monsoonal circulation implies seasonally reversing winds. Hence, at low northern latitudes of western Pangea, the zonal easterlies predominant during the Northern Hemisphere winter would yield to monsoonal westerlies during the Northern Hemisphere summer. Additionally, models of Early Permian climate under varying conditions of icehouse and greenhouse states show a meridional component of circulation with flow from the Central Pangean Mountains toward the Southern Hemisphere (i.e., southerlies/ southeasterlies in low northern latitudes of western Pangea; Heavens et al., 2015). Glacial conditions weaken the summer monsoon and strengthen the winter monsoon (Heavens et al., 2015); hence, seasonal southerlies and westerlies would have presumably grown progressively stronger through the Permian. If Ancestral Rocky Mountains sources persisted throughout Permian time, then Yavapai-Mazatzal sources should have increased in importance through time as the monsoon strength- ened, but they decrease, consistent with subsidence of these sources, and enhancement of Grenville and Paleozoic sources from the south/southeast.

\section{CONCLUSIONS}

Although several recent provenance studies have focused on specific intervals in the Permian section of the western and midcontinent United States, the RKB core, supplemented by study of correlative units in outcrop, provides a rare opportunity to document temporal changes in deposition and provenance that span nearly the entire Permian record of the southern midcontinent. In this region, this interval records no unequivocal evidence for marine deposition, excepting clearly marine limestone of the lowest Permian section, no evidence for deltaic or tidal sedimentation, and only minimal evidence for fluvial deposition. The remainder of the section, which consists entirely of fine-grained siliciclastic strata with varying presence of evaporites, is interpreted to record predominantly eolian transport. More specifically, these red bed strata are interpreted to record eolian delivery of silt, clay, and relatively minor sand, and ultimate deposition in environments ranging from eolian (loess, dune, or sheet sands) to mud flat (commonly saline), with limited reworking in wadi-type small ephemeral fluvial channels. Application of detrital-zircon geochronology to these strata indicates a first-order provenance shift in the Permian, with primarily southeastern and western sources in the Early Permian evolving to an increasing influence of southern and southeastern sources in the later Permian. This shift is interpreted to reflect both tectonic and climatic controls: (1) The Ancestral Rocky Mountains uplifts of western equatorial Pangea were actively eroding in the Pennsylvanian and earliest Permian, and they diminished as first-cycle sources by late Early Permian time, as sources located south (in Mexico and Central America) were uplifted and eroded to join material derived from the south and east (Appalachian-Ouachita system). (2) The Pangean monsoon strengthened as the Permian icehouse receded, resulting in increasing ease of transport of sediment from the west as well as the south and southeast. Sediment blowing toward the midcontinent from the west was likely derived from transitional marine systems along the western margin of Pangea and was transported across the remnant (subdued) Ancestral Rocky Mountains uplifts (cf. M.J. Soreghan et al., 2002, 2008, 2014; Lawton et al., 2015).

Permian strata of the southern midcontinent thus reflect the operation of localized fluvial systems emanating from orogens south and southeast that terminated before reaching the study area. The increasing aridity affecting this area through Permian time likely resulted in development of terminal-splay systems, from which sediment was deflated to form loessitic and eoliansand systems that were ultimately trapped within the broadly subsiding sink of the southern midcontinent, as well as sediment blown across western North America that buried the old orogens of the Ancestral Rocky Mountains in a wash of sediment derived from the Central Pangean suture. 


\section{ACKNOWLEDGMENTS}

This $10 \mathrm{yr}$ research project on midcontinent Permian red beds was supported primarily by funding from the National Science Foundation (EAR-0746042, EAR-1053018, and EAR-1338331). Any opinions, findings, and conclusions or recommendations expressed in this material are those of the author(s) and do not necessarily reflect the view of the National Science Foundation. We thank George Gehrels (University of Arizona) and his staff for help with logistics and assisting us in analyses at the University of Arizona's LaserChron facility. We thank Mike Hamilton (University of Toronto) and Kathleen Benison (West Virginia University) for ongoing discussions on detrital-zircon geochronology and Permian red beds, respectively. Elizabeth Gergurich helped sample and analyze some of the samples; several University of Oklahoma students facilitated field work during prior collection of samples. We thank reviewers David Barbeau and Paul Link for insightful comments and helpful comments that greatly improved this manuscript, and Volume Editor Ray Ingersoll, who provided his own careful review, for greatly improving the clarity of the manuscript. This paper is dedicated to the memory of William R. Dickinson, who was such an influential advisor, mentor, and teacher for both G.S. and M.J. Soreghan.

\section{REFERENCES CITED}

Allen, J.P., Fielding, C.R., Gibling, M.R., and Rygel, M.C., 2011, Fluvial response to paleo-equatorial climate fluctuations during the late Paleozoic ice age: Geological Society of America Bulletin, v. 123, p. 1524-1538, https://doi.org/10.1130/B30314.1.

Becker, T.P., 2005, Paleogeographic and Tectonic Implications of the Late Paleozoic Alleghanian Orogen Developed from Isotopic Sedimentary Provenance Proxies from the Appalachian Foreland Basin [Ph.D. thesis]: Lexington, Kentucky, University of Kentucky, 214 p.

Becker, T.P., Thomas, W.A., and Gehrels, G.E., 2006, Linking late Paleozoic sedimentary provenance in the Appalachian Basin to the history of Alleghanian deformation: American Journal of Science, v. 306, p. 777798, https://doi.org/10.2475/10.2006.01

Becq-Giraudon, J.F., Montenat, C., and Van Den Driessche, J., 1996, Hercynian high-altitude phenomena in the French Massif Central: Tectonic implications: Palaeogeography, Palaeoclimatology, Palaeoecology, v. 122, p. 227-241, https://doi.org/10.1016/0031-0182(95)00081-X.

Benison, K.C., and Goldstein, R.H., 2000, Sedimentology of ancient saline pans: An example from the Permian Opeche Shale, Williston Basin, North Dakota, USA: Journal of Sedimentary Research, v. 70, p. 159-169, https://doi.org/10.1306/2DC40907-0E47-11D7-8643000102C1865D.

Benison, K.C., and Goldstein, R.H., 2001, Evaporites and siliciclastics of the Permian Nippewalla Group of Kansas, USA: A case for non-marine deposition in saline lakes and saline pans: Sedimentology, v. 48, p. $165-188$, https://doi.org/10.1046/j.1365-3091.2001.00362.x.

Benison, K.C., Goldstein, R.H., Wopenka, B., Burruss, R.C., and Pasteris, J.D., 1998, Extremely acid Permian lakes and groundwaters in North America: Nature, v. 392, p. 911-914, https://doi.org/10.1038/31917.

Benison, K.C., Zambito, J.J., IV, Soreghan, G.S., Soreghan, M.J., Foster, T.M., and Kane, M., 2013, Permian red beds and evaporites of the Amoco Rebecca K. Bounds core, Greeley County, Kansas: Implications for science and industry, in Watney, W.L., Dubois, M.K., and Tollefson, J., eds., Mid-Continent Core Workshop: From Source to Reservoir to Seal: Wichita, Kansas Geological Survey and Kansas Geological Society, p. 9-14. https://doi.org/10.13140/RG2.1.3170.7603 9-14.

Boucot, A.J., Xu, C., and Scotese, C.R., 2013, Phanerozoic Paleoclimate: An Atlas of Lithologic Indicators of Climate: Society for Sedimentary Geology (SEPM) Concepts in Sedimentology and Paleontology 11, 478 p.
Bream, B.R., 2002, The Southern Appalachian Inner Piedmont: New perspectives based on recent detailed geologic mapping, $\mathrm{Nd}$ isotopic evidence, and zircon geochronology, in Hatcher, R.D., Jr., and Bream, B.R., eds., Inner Piedmont Geology in the South Mountains-Blue Ridge Foothills and the Southwestern Brushy Mountains, Central-Western North Carolina: Raleigh, North Carolina, North Carolina Geological Survey, Carolina Geological Society Annual Field Trip Guidebook, p. 45-63.

Breit, G.N., Rice, C., Esposito, K., and Schlottmann, J.L., 1990, Mineralogy and Petrography of Permian Rocks in the Central Oklahoma Aquifer: U.S. Geological Survey Open-File Report 90-678, 50 p.

Brewer, R., 1976, Fabric and Mineral Analysis of Soils: New York, John Wiley and Sons, $482 \mathrm{p}$.

Briden, J.C., and Irving, E., 1964, Paleolatitude spectra of sedimentary paleoclimate indicators, in Nairn, A.E.M., ed., Problems in Paleoclimatology: London, Wiley, p. 199-224.

Brillo, V.M.D., 2015, Age, Provenance, and Facies Architecture of an AridLand Fluvial System in Equatorial Pangaea: The Cloud Chief Formation in Western Oklahoma, U.S.A. [M.S. thesis]: Santa Barbara, California, University of California, $92 \mathrm{p}$.

Cater, F.W., Jr., 1970, Geology of the Salt Anticline Region in Southwestern Colorado: U.S. Geological Survey Professional Paper 637, 80 p.

Crowell, J.C., 1999, Pre-Mesozoic Ice Ages: Their Bearing on Understanding the Climate System: Geological Society of America Memoir 192, 106 p.

Dickinson, W.R., 2008, Impact of differential zircon fertility of granitoid basement rocks in North America on age populations of detrital zircons and implications for granite petrogenesis: Earth and Planetary Science Letters, v. 275, p. 80-92, https://doi.org/10.1016/j.eps1.2008.08.003.

Dickinson, W.R., and Gehrels, G.E., 2003, U-Pb ages of detrital zircons from Permian and Jurassic eolian sandstones of the Colorado Plateau, USA: Paleogeographic implications: Sedimentary Geology, v. 163, p. 29-66, https://doi.org/10.1016/S0037-0738(03)00158-1.

Dickinson, W.R., and Lawton, T.F., 2001, Carboniferous to Cretaceous assembly and fragmentation of Mexico: Geological Society of America Bulletin, v. 113, p. 1142-1160, https://doi.org/10.1130/0016-7606 (2001) $113<1142:$ CTCAAF $>2.0 . C O ; 2$.

Dickinson, W.R., and Lawton, T.F., 2003, Sequential intercontinental suturing as the ultimate control for Pennsylvanian Ancestral Rocky Mountains deformation: Geology, v. 31, p. 609-612, https://doi.org/10.1130/0091 -7613(2003)031<0609:SISATU>2.0.CO;2.

Dickinson, W.R., Gehrels, G.E., and Stern, R., 2010, Late Triassic Texas uplift preceding Jurassic opening of the Gulf of Mexico: Evidence from $\mathrm{U}-\mathrm{Pb}$ ages of detrital zircons: Geosphere, v. 6, p. 641-662, https://doi .org/10.1130/GES00532.1.

Dubiel, R.F., Parrish, J.T., Parrish, J.M., and Good, S.C., 1991, The Pangaean megamonsoon-Evidence from the Upper Triassic Chinle Formation, Colorado Plateau: Palaios, v. 6, p. 347-370, https://doi.org/10.2307/3514963.

Dubois, M.K., Goldstein, R.H., and Hasiotis, S.T., 2012, Climate-controlled aggradation and cyclicity of continental loessic siliciclastic sediments in Asselian-Sakmarian cyclothems, Permian, Hugoton embayment, USA: Sedimentology, v. 59, p. 1782-1816, https://doi.org/10.1111/j.1365-3091 .2012.01326.x.

Eriksson, K.A., Campbell, I.H., Palin, J.M., Allen, C.M., and Bock, B., 2004, Evidence for multiple recycling in Neoproterozoic through Pennsylvanian sedimentary rocks of the central Appalachian Basin: Journal of Geology, v. 112, p. 261-276, https://doi.org/10.1086/382758.

Evans, D.A.D., 2003, A fundamental Precambrian-Phanerozoic shift in Earth's glacial style: Tectonophysics, v. 375, p. 353-385, https://doi.org/10.1016/ S0040-1951(03)00345-7.

Fay, R.O., 1962, Geology and Mineral Resources of Blaine County, Oklahoma: Oklahoma Geological Survey Bulletin 89, 258 p.

Fay, R.O., 1964, The Blaine and Related Formations of Northwestern Oklahoma and Southern Kansas: Oklahoma Geological Survey Bulletin 98, 238 p.

Fay, R.O., and Hart, D.L., Jr., 1978, Geology and Mineral Resources (Exclusive of Petroleum) of Custer County, Oklahoma: Oklahoma Geological Survey Bulletin 114, 88 p.

Fielding, T.D., Frank, T.D., and Isbell, J.L., 2008, The late Paleozoic ice ageA review of current understanding and synthesis of global climate patterns, in Fielding, C.R., Frank, T.D., and Isbell, J.L., eds., Resolving the Late Paleozoic Ice Age in Time and Space: Geological Society of America Special Paper 441, p. 343-354, https://doi.org/10.1130/2008.2441(24). 
Foster, G.L., Royer, D.L., and Lunt, D.J., 2017, Future climate forcing potentially without precedent in the last 420 million years: Nature Communications, v. 8, 14845, https://doi.org/10.1038/ncomms14845.

Foster, T.M., Soreghan, G.S., Soreghan, M.J., Benison, K.C., and Elmore, R.D., 2014, Climatic and paleogeographic significance of eolian sediment in the Middle Permian Dog Creek Shale (midcontinent U.S.): Palaeogeography, Palaeoclimatology, Palaeoecology, v. 402, p. 12-29, https:// doi.org/10.1016/j.palaeo.2014.02.031.

Frakes, L.A., 1992, The cool mode: Early Carboniferous to late Permian, in Frakes, L.A., Francis, J.E., and Syktus, J.I., eds., The History of the Earth's Climate over the Past 600 Million Years: UK, Cambridge, Cambridge University Press, p. 37-55, https://doi.org/10.1017/ CBO9780511628948.006.

Frizon de Lamotte, D., Fourdan, B., Leleu, S., Leparmentier, F., and de Clarens, P., 2015, Style of rifting and the stages of Pangea breakup: Tectonics, v. 34, p. 1009-1029, https://doi.org/10.1002/2014TC003760.

Gergurich, E.L., 2015, Sedimentologic and Provenance Analysis of Middle Permian Siliciclastics in Western Equatorial Pangea (WY, KS, OK, TX) [M.S. thesis]: Norman, Oklahoma, University of Oklahoma, 139 p.

Gehrels, G.E., and Pecha, M., 2014, Detrital zircon U-Pb geochronology and Hf isotope geochemistry of Paleozoic and Triassic passive margin strata of western North America: Geosphere, v. 10, p. 49-65, https://doi .org/10.1130/GES00889.1.

Gehrels, G.E., Victor, V.A., and Pullen, A., 2006, Detrital zircon geochronology by laser-ablation multicollector ICPMS at the Arizona LaserChron Center, in Loszewski, $T$., and Huff, W., eds., Geochronology: Emerging Opportunities: The Paleontological Society Papers 12, p. 67-76, https:// doi.org/10.1017/S1089332600001352.

Gehrels, G.E., Blakey, R., Karlstrom, K.E., Timmons, J.M., Dickinson, B., and Pecha, M., 2011, Detrital zircon U-Pb geochronology of Paleozoic strata in the Grand Canyon, Arizona: Lithosphere, v. 3, p. 183-200, https://doi .org/10.1130/L121.1

Giles, J.M., Soreghan, M.J., Benison, K.C., Soreghan, G.S., and Hasiotis, S.T., 2013, Lakes, loess, and paleosols in the Permian Wellington Formation of Oklahoma, U.S.A.: Implications for paleoclimate and paleogeography of the midcontinent: Journal of Sedimentary Research, v. 83, p. 825-846, https://doi.org/10.2110/jsr.2013.59.

Gillis, R.J., Gehrels, G.E., Ruiz, J., and Gonzalez, L.A.F.D., 2005, Detrital zircon provenance of Cambrian-Ordovician and Carboniferous strata of the Oaxaca terrane, southern Mexico: Sedimentary Geology, v. 182, p. 87-100, https://doi.org/10.1016/j.sedgeo.2005.07.013.

Gleason, J.D., Gehrels, G.E., Dickinson, W.R., Patchett, P.J., and Kring, D., 2007, Laurentian sources for detrital zircon grains in turbidite and deltaic sandstones of the Pennsylvanian Haymond Formation, Marathon assemblage, west Texas, U.S.A.: Journal of Sedimentary Research, v. 77, p. 888-900, https://doi.org/10.2110/jsr.2007.084.

Ham, W.E., 1960, Middle Permian evaporites in southwestern Oklahoma, in 21st International Geologic Congress, Report 12, Copenhagen, p. 138-151.

Ham, W.E., Denison, R.E., and Merritt, C.A., 1964, Basement Rocks and Structural Evolution of Southern Oklahoma: Oklahoma Geological Survey Bulletin 95, $302 \mathrm{p}$.

Heavens, N.G., Mahowald, N.M., Soreghan, G.S., Soreghan, M.J., and Shields, C.A., 2015, A model-based evaluation of tropical climate in Pangaea during the late Palaeozoic icehouse: Palaeogeography, Palaeoclimatology, Palaeoecology, v. 425, p. 109-127, https://doi.org/10.1016/j .palaeo.2015.02.024

Heckel, P.H., 2008, Pennsylvanian cyclothems in midcontinent North America as far-field effects of waxing and waning of Gondwana ice sheets, in Fielding, C.R., Frank, T.D., and Isbell, J.L., eds., Resolving the Late Paleozoic Ice Age in Time and Space: Geological Society of America Special Paper 441, p. 275-289, https://doi.org/10.1130/2008.2441(19).

Heckel, P.H., Gibling, M.R., and King, N.R., 1998, Stratigraphic model for glacial-eustatic Pennsylvanian cyclothems in highstand nearshore detrital regimes: The Journal of Geology, v. 106, p. 373-384, https://doi.org/ $10.1086 / 516030$

Hills, J.M., 1942, Rhythm of Permian seas-A paleogeographic study: American Association of Petroleum Geologists Bulletin, v. 26, p. 217-255.

Hoffman, P.F., 1989, Precambrian geology and tectonic history of North America, in Bally, A.W., and Palmer, A.R., eds., The Geology of North America-An Overview: Boulder, Colorado, Geological Society of America, Geology of North America, v. A, p. 447-512, https://doi.org/10 .1130/DNAG-GNA-A.447.
Johnson, K.S., 1967, Stratigraphy of the Permian Blaine Formation and Associated Strata in Southwestern Oklahoma [Ph.D. thesis]: Norman, Oklahoma, University of Oklahoma, $247 \mathrm{p}$.

Johnson, K.S., 1988, Pennsylvanian and Permian Rocks, Oklahoma: Oklahoma Geological Survey Circular 90, p. 12-35.

Johnston, S., Gehrels, G.E., and Valencia, V.J.R., 2009, Small-volume $\mathrm{U}-\mathrm{Pb}$ zircon geochronology by laser ablation-multicollector-ICPMS: Chemical Geology, v. 259, p. 218-229, https://doi.org/10.1016/j .chemgeo.2008.11.004.

Karlstrom, K.E., Williams, M.L., Hawkins, D.P., Bowring, S.A., and Seaman, S.J., 2003, Paleoproterozoic rocks of the Granite Gorges, in Beus, S.S., and Morales, M., eds., Grand Canyon Geology: New York, Oxford University Press, p. 9-38.

Keppie, J.D., Sandberg, C.A., Miller, B.V., Sanchez-Zavala, J.L., Nance, R.D., and Poole, F.G., 2004, Implications of latest Pennsylvanian to Middle Permian paleontological and U-Pb SHRIMP data from the Tecomate Formation to re-dating tectonothermal events in the Acatlán Complex, southern Mexico: International Geology Review, v. 46, p. 745-753, https://doi .org/10.2747/0020-6814.46.8.745

Kessler, J.P., Soreghan, G.S., and Wacker, H., 2001, Equatorial aridity in western Pangea: Lower Permian loessite and dolomitic paleosols in northeastern New Mexico, USA: Journal of Sedimentary Research, v. 71, p. 817-832, https://doi.org/10.1306/2DC4096B-0E47-11D7-8643000102C1865D.

Kluth, C.F., 1986, Plate tectonics of the ancestral Rocky Mountains, in Peterson, J.A., ed., Paleotectonics and Sedimentation in the Rocky Mountain Region: American Association of Petroleum Geologists Memoir 41, p. 353-369.

Kluth, C.F., and Coney, P.J., 1981, Plate tectonics of the ancestral Rocky Mountains: Geology, v. 9, p. 10-15, https://doi.org/10.1130/0091-7613 (1981) $9<10$ :PTOTAR>2.0.CO;2.

Kocurek, G., and Kirkland, B.L., 1998, Getting to the source: Aeolian influx to the Permian Delaware basin region: Sedimentary Geology, v. 117, p. 143 149, https://doi.org/10.1016/S0037-0738(98)00024-4.

Lawrence, R.L., Cox, R., Mapes, R.W., and Coleman, D.S., 2011, Hydrodynamic fractionation of zircon age populations: Geological Society of America Bulletin, v. 123, p. 295-305, https://doi.org/10.1130/B30151.1.

Lawton, T.F., Buller, C.D., and Parr, T.R., 2015, Provenance of a Permian erg on the western margin of Pangea: Depositional system of the Kungurian (late Leonardian) Castle Valley and White Rim sandstones and subjacent Cutler Group, Paradox Basin, Utah, USA: Geosphere, v. 11, p. 1475-1506, https://doi.org/10.1130/GES01174.1.

Leary, R.J., Umhoefer, P., Smith, M.E., and Riggs, N., 2017, A three-sided orogen: A new tectonic model for Ancestral Rocky Mountain uplift and basin development: Geology, v. 45, p. 735-738, https://doi.org/10.1130/G39041.1.

Link, P.K., Mahon, R.C., Beranek, L.P., Campbell-Stone, E.A., and Lynds, R., 2014, Detrital zircon provenance of Pennsylvanian to Permian sandstones from the Wyoming craton and Wood River Basin, Idaho, USA: Rocky Mountain Geology, v. 49, p. 115-136, https://doi.org/10.2113/ gsrocky.49.2.115.

Martens, U., Weber, B., and Valencia, V.A., 2010, U/Pb geochronology of Devonian and older Paleozoic beds in the southeastern Maya block, Central America: Its affinity with peri-Gondwanan terranes: Geological Society of America Bulletin, v. 122, p. 815-829, https://doi.org/10.1130/ B26405.1.

McKee, E.D., and Oriel, S.S., 1967, Paleotectonic Investigations of the Permian Systems in the United States: U.S. Geological Survey Professional Paper $515,268 \mathrm{p}$.

McLennan, S.M., Bock, B., Compston, W., Hemming, S.R., and McDaniel, D.K., 2001, Detrital zircon geochronology of Taconian and Acadian foreland sedimentary rocks in New England: Journal of Sedimentary Research, v. 71, p. 305-317, https://doi.org/10.1306/072600710305.

Moecher, D., and Samson, S., 2006, Differential zircon fertility of source terranes and natural bias in the detrital zircon record: Implications for sedimentary provenance analysis: Earth and Planetary Science Letters, v. 247, p. 252-266, https://doi.org/10.1016/j.eps1.2006.04.035.

Montañez, I.P., and Poulsen, C.J., 2013, The late Paleozoic ice age: An evolving paradigm: Annual Review of Earth and Planetary Sciences, v. 41, p. 629656, https://doi.org/10.1146/annurev.earth.031208.100118.

Mueller, P.A., Heatherington, A.L., Wooden, J.L., Shuster, R.D., Nutman, A.P., and Williams, I.S., 1994, Precambrian zircons from the Florida basement: A Gondwanan connection: Geology, v. 22, p. 119-122, https://doi .org/10.1130/0091-7613(1994)022<0119:PZFTFB >2.3.CO;2. 
Murphy, J.B., Pisarevsky, S.A., Nance, R.D., and Keppie, J.D., 2004, Neoproterozoic-early Paleozoic evolution of peri-Gondwanan terranes: Implications for Laurentia-Gondwana connections: International Journal of Earth Sciences, v. 93, p. 659-682, https://doi.org/10.1007/s00531-004-0412-9.

Nance, R.D., and Thompson, M.D., 1996, Avalonian and related peri-Gondwanan terranes of the Circum-North Atlantic: An introduction, in Nance, R.D., and Thompson, M.D., eds., Avalonian and Related Peri-Gondwanan Terranes of the Circum-North Atlantic: Geological Society of America Special Paper 304, p. 1-7, https://doi.org/10.1130/0-8137-2304-3.1.

Opdyke, N.D., Jones, D.S., Macfadden, B.J., Smith, D.L., Mueller, P.A., and Shuster, R.D., 1987, Florida as an exotic terrane: Paleomagnetic and geochronologic investigation of Lower Paleozoic rocks from the subsurface of Florida: Geology, v. 15, p. 900-903, https://doi.org/10.1130/0091 -7613(1987) 15<900:FAAETP > 2.0.CO;2.

Park, H., Barbeau, D.L., Jr., Rickenbaker, A., Bachmann-Krug, D., and Gehrels, G., 2010, Application of foreland basin detrital-zircon geochronology to the reconstruction of the southern and central Appalachian orogeny: Journal of Geology, v. 118, p. 23-44, https://doi.org/10.1086/648400.

Parrish, J.T., 1993, Climate of the supercontinent Pangea: The Journal of Geology, v. 101, p. 215-233, https://doi.org/10.1086/648217.

Peterson, F., 1988, Stratigraphy and nomenclature of Middle and Upper Jurassic rocks, western Colorado Plateau, Utah and Arizona, in Revisions to Stratigraphic Nomenclature of Jurassic and Cretaceous Rocks of the Colorado Plateau: U.S. Geological Survey Bulletin 1633-B, p. B13-B56.

Piper, D.Z., and Link, P.K., 2002, An upwelling model for the Phosphoria Sea: A Permian, ocean-margin sea in the northwest United States: American Association of Petroleum Geologists Bulletin, v. 86, p. 1217-1235.

Poland, Z.A., and Simms, A.R., 2012, Sedimentology of an erg to an erg-margin depositional system, the Rush Springs Sandstone of western Oklahoma, U.S.A.: Implications for paleowinds across northwestern Pangea during the Guadalupian (Middle Permian): Journal of Sedimentary Research, v. 82, p. 345-363, https://doi.org/10.2110/jsr.2012.32.

Pollock, J.C., Hibbard, J.P., and van Staal, C.R., 2012, A paleogeographical review of the peri-Gondwanan realm of the Appalachian orogen: Canadian Journal of Earth Sciences, v. 49, p. 259-288, https://doi.org/ 10.1139/e11-049.

Poole, F., Perry, W., Madrid, R., and Amaya-Martinez, R., 2005, Tectonic synthesis of the Ouachita-Marathon-Sonora orogenic margin of southern Laurentia: Stratigraphic and structural implications for timing of deformational events and plate-tectonic model, in Anderson, T.H., Nourse, J.A., McKee, J.W., and Steiner, M.B., eds., The Mojave-Sonora Megashear Hypothesis: Development, Assessment, and Alternatives: Geological Society of America Special Paper 393, p. 543-596, https://doi .org/10.1130/0-8137-2393-0.543.

Rainbird, R.H., Heaman, L.M., and Young, G.M., 1992, Sampling Laurentia: Detrital zircon geochronology offers evidence for an extensive Neoproterozoic river system originating from Grenville orogen: Geology, v. 20, p. 351-354, https://doi.org/10.1130/0091-7613(1992)020<0351 :SLDZGO $>2.3 . \mathrm{CO} ; 2$.

Rainbird, R.H., McNicoll, V.J., Heaman, L.M., Abbott, J.G., Long, D.G.F., and Thorkelson, D.J., 1997, Pan-continental river system draining Grenville orogen recorded by $\mathrm{U}-\mathrm{Pb}$ and $\mathrm{Sm}-\mathrm{Nd}$ geochronology of Neoproterozoic quartzarenites and mudrocks, northwestern Canada: The Journal of Geology, v. 105, p. 1-17, https://doi.org/10.1086/606144.

Rainbird, R.H., Cawood, P., and Gehrels, G.E., 2012, The great Grenvillian sedimentation episode: Record of supercontinent Rodinia's assembly, in Busby, C., and Azor, A., eds., Tectonics of Sedimentary Basins: Recent Advances: Hoboken, New Jersey, Wiley-Blackwell, p. 583-601, https:// doi.org/10.1002/9781444347166.ch29.

Rankin, D.W., Drake, A.A., Jr., Glover, L., III, Goldsmith, R., Hall, L.M., Murray, D.P., Ratcliffe, N.M., Read, J.F., Secor, D.T., Jr., and Stanley, R.S., 1989, Pre-orogenic terranes, in Hatcher, R.D., Jr., Thomas, W.A., and Viele, G.W., eds., The Appalachian-Ouachita Orogen in the United States: Boulder, Colorado, Geological Society of America, Geology of North America, v. F-2, p. 7-100.

Sacks, P.E., and Secor, D.T., Jr., 1990, Kinematics of late Paleozoic continental collision between Laurentia and Gondwana: Science, v. 250, p. $1702-$ 1705, https://doi.org/10.1126/science.250.4988.1702.

Scotese, C.R., and McKerrow, W.S., 1990, Revised world maps and introduction, in McKerrow, W.S., and Scotese, C.R., eds., Paleozoic Palaeogeography and Biogeography: Geological Society of London Memoir 12, p. $1-21$.
Scotese, C.R., Bambach, R.K., Barton, C., Van Der Voo, R., and Ziegler, A.M., 1979, Paleozoic base maps: The Journal of Geology, v. 87, p. 217-277, https://doi.org/10.1086/628416.

Self, R.P., 1966, Petrology of the Duncan Sandstone (Permian) of SouthCentral Oklahoma [M.S. thesis]: Norman, Oklahoma, University of Oklahoma, $133 \mathrm{p}$.

Sharrah, K.L., 2006, Comparative Study of the Sedimentology and Provenance of the Atoka Formation in the Frontal Ouachita Thrust Belt, Oklahoma [Ph.D. thesis]: Tulsa, Oklahoma, University of Tulsa, $268 \mathrm{p}$.

Simpson, L.C., Harrington, J.M., and Johnson, K.S., 1999, Hydrogeology of the Garber-Wellington aquifer in Oklahoma City, Oklahoma, USA: International Contributions to Hydrogeology, v. 21, p. 245-250.

Soreghan, G.S., 1994, The impact of glacioclimatic change on Pennsylvanian cyclostratigraphy, in Embry, A.F., Beauchamp, B., and Glass, D.J., eds., Pangea: Global Environments and Resources: Canadian Society of Petroleum Geologists Memoir 17, p. 523-543.

Soreghan, G.S., and Soreghan, M.J., 2013, Tracing clastic delivery to the Permian Delaware Basin, U.S.A.: Implications for paleogeography and circulation in westernmost equatorial Pangea: Journal of Sedimentary Research, v. 83, p. 786-802, https://doi.org/10.2110/jsr.2013.63.

Soreghan, G.S., Moses, A.M., Soreghan, M.J., Hamilton, M.A., Fanning, M.C., and Link, P.K., 2007, Palaeoclimatic inferences from Upper Palaeozoic siltstone of the Earp Formation and equivalents, Arizona-New Mexico (USA): Sedimentology, v. 54, p. 701-719, https://doi.org/10.1111/j.1365 -3091.2007.00857.x.

Soreghan, G.S., Soreghan, M.J., Poulsen, C., Young, R.Y., Eble, C., Sweet, D.E., and Davogustto, O., 2008a, Anomalous cold in the Pangaean tropics: Geology, v. 36, p. 659-662, https://doi.org/10.1130/G24822A.1.

Soreghan, G.S., Soreghan, M.J., and Hamilton, M.A., 2008b, Origin and significance of loess in late Paleozoic western Pangaea: A record of tropical cold?: Palaeogeography, Palaeoclimatology, Palaeoecology, v. 268, p. 234-259, https://doi.org/10.1016/j.palaeo.2008.03.050.

Soreghan, G.S., Keller, G.R., Gilbert, M.C., Chase, C.G., and Sweet, D.E., 2012, Load-induced subsidence of the Ancestral Rocky Mountains recorded by preservation of Permian landscapes: Geosphere, v. 8, p. 654-668, https:// doi.org/10.1130/GES00681.1.

Soreghan, G.S., Sweet, D.E., and Heavens, N.G., 2014, Upland glaciation in tropical Pangaea: Geologic evidence and implications for late Paleozoic climate modeling: The Journal of Geology, v. 122, p. 137-163, https://doi .org/10.1086/675255.

Soreghan, M.J., Soreghan, G.S., and Hamilton, M.A., 2002, Paleowinds inferred from detrital-zircon geochronology of Upper Paleozoic loessite, western equatorial Pangea: Geology, v. 30, p. 695-698, https://doi .org/10.1130/0091-7613(2002)030<0695:PIFDZG>2.0.CO;2.

Soreghan, M.J., Soreghan, G.S., and Hamilton, M.A., 2008, Glacial-interglacial shifts in atmospheric circulation of western tropical Pangea: Palaeogeography, Palaeoclimatology, Palaeoecology, v. 268, p. 260-272, https:// doi.org/10.1016/j.palaeo.2008.03.051.

Soreghan, M.J., Heavens, N.G., Soreghan, G.S., Link, P.K., and Hamilton, M.A., 2014, Abrupt and high-magnitude changes in atmospheric circulation recorded in the Permian Maroon Formation, tropical Pangaea: Geological Society of America Bulletin, v. 126, p. 569-584, https://doi .org/10.1130/B30840.1.

Steeples, D.W., 1989, Structure of the Salina-Forest City interbasin boundary from seismic studies, in Steeples, D.W., ed., Geophysics in Kansas: Kansas Geological Survey Bulletin 226, p. 31-52.

Sutherland, P.K., 1988, Late Mississippian and Pennsylvanian depositional history in the Arkoma Basin area, Oklahoma and Arkansas: Geological Society of America Bulletin, v. 100, p. 1787-1802, https://doi.org/ 10.1130/0016-7606(1988)100<1787:LMAPDH>2.3.CO;2.

Sweet, A.A., Soreghan, G.S., Sweet, D.E., Soreghan, M.J., and Madden, A.S., 2013, Permian dust in Oklahoma: Source and origin for Middle Permian (Flowerpot-Blaine) redbeds in western tropical Pangaea: Sedimentary Geology, v. 284-285, p. 181-196, https://doi.org/10.1016/j .sedgeo.2012.12.006.

Tabor, N.J., and Montañez, I.P., 2002, Shifts in late Paleozoic atmospheric circulation over western equatorial Pangea; insights from pedogenic mineral $\delta^{18} \mathrm{O}$ compositions: Geology, v. 30 , p. $1127-1130$, https://doi .org/10.1130/0091-7613(2002)030<1127:SILPAC >2.0.CO;2.

Tabor, N.J., and Montañez, I.P., 2004, Morphology and distribution of fossil soils in the Permo-Pennsylvanian Bowie and Wichita Groups, northcentral Texas, USA: Their implications for western equatorial Pangean 
palaeoclimate during icehouse-greenhouse transition: Sedimentology, v. 51, p. 851-884, https://doi.org/10.1111/j.1365-3091.2004.00655.x.

Tabor, N.J., and Poulsen, C.J., 2008, Palaeoclimate across the late Pennsylvanian-Early Permian tropical palaeolatitudes: A review of climate indicators, their distribution, and relation to palaeophysiographic climate factors: Palaeogeography, Palaeoclimatology, Palaeoecology, v. 268, p. 293-310, https://doi.org/10.1016/j.palaeo.2008.03.052.

Tandon, S.K., and Gibling, M.R., 1994, Calcrete and coal in late Carboniferous cyclothems of Nova Scotia, Canada: Climate and sea-level changes linked: Geology, v. 22, p. 755-758, https://doi.org/10.1130/0091-7613 (1994)022<0755:CACILC>2.3.CO;2.

Thomas, W.A., 1985, The Appalachian-Ouachita connection: Paleozoic orogenic belt at the southern margin of North America: Annual Review of Earth and Planetary Science, v. 13, p. 175-199, https://doi.org/10.1146/ annurev.ea.13.050185.001135.

Thomas, W.A., 2011, Detrital-zircon geochronology and sedimentary provenance: Lithosphere, v. 3, p. 304-308, https://doi.org/10.1130/RF.L001.1.

Thomas, W.A., Becker, T.P., Samson, S.D., and Hamilton, M.A., 2004, Detrital zircon evidence of a recycled orogenic foreland provenance for Alleghanian clastic-wedge sandstones: The Journal of Geology, v. 112, p. 23-37, https://doi.org/10.1086/379690.

Thompson, M.D., Barr, S.M., and Grunow, A.M., 2012, Avalonian perspectives on Neoproterozoic paleogeography: Evidence from Sm-Nd isotope geochemistry and detrital zircon geochronology in SE New England, USA Geological Society of America Bulletin, v. 124, p. 517-531, https://doi .org/10.1130/B30529.1.

Trexler, J., Cashman, P., Snyder, W., and Davydov, V.D., 2004, Late Paleozoic tectonism in Nevada: Timing, kinematics, and tectonic significance: Geological Society of America Bulletin, v. 116, p. 525-538, https://doi .org/10.1130/B25295.1.

Van Schmus, W.R., Bickford, M.E., Sims, P.K., Anderson, J.L., Shearer, C.K. and Treves, S.B., 1993, Proterozoic geology of the western midcontinent region, in Reed, J.C., Bickford, M.E., Houston, R.S., Link, P.K., Rankin, D.W., Sims, P.K., and Van Schmus, W.R., eds., Precambrian Conterminous U.S.: Boulder, Colorado, Geological Society of America, Geology of North America, v. C-2, p. 239-259.

Van Schmus, W.R., Bickford, M.E., and Turek, A., 1996, Proterozoic geology of the east-central Midcontinent basement, in van der Pluijm, B.A., and Catacosinos, P.A., eds., Basement and Basins of Eastern North America: Geological Society of America Special Paper 308, p. 7-32, https://doi .org/10.1130/0-8137-2308-6.7

Veevers, J.J., and Powell, M., 1987, Late Paleozoic glacial episodes in Gondwanaland reflected in transgressive-regressive depositional sequences in Euramerica: Geological Society of America Bulletin, v. 98, p. 475-487, https://doi.org/10.1130/0016-7606(1987)98<475:LPGEIG>2.0.CO;2.

Vega-Granillo, R., Salgado-Souto, S., and Talavera-Mendoza, O., 2008, U-Pb detrital zircon data of the Rio Fuerte Formation (NW Mexico): Its periGondwanan provenance and exotic nature in relation to southwestern
North America: Journal of South American Earth Sciences, v. 26, p. 343 354, https://doi.org/10.1016/j.jsames.2008.08.011.

Viele, G.W., and Thomas, W.A., 1989, Tectonic synthesis of the Ouachita orogenic belt, in Hatcher, R.D., Thomas, W.A., and Viele, G.W., eds., The Appalachian-Ouachita Orogen in the United States: Boulder, Colorado, Geological Society of America, Geology of North America, v. F-2, p. 695-728, https://doi.org/10.1130/DNAG-GNA-F2.695.

Voigt, S., Lucas, S.G., and Krainer, K., 2013, Coastal-plain origin of trace-fossil bearing red beds in the Early Permian of southern New Mexico, U.S.A.: Palaeogeography, Palaeoclimatology, Palaeoecology, v. 369, p. 323-334, https://doi.org/10.1016/j.palaeo.2012.10.041.

Weber, B., Schaaf, P., Valencia, V.A., Iriondo, A., and Ortega-Gutierrez, F., 2006, Provenance ages of late Paleozoic sandstones (Santa Rosa Formation) from the Maya block, SE Mexico: Implications on the tectonic evolution of western Pangea: Revista Mexicana de Ciencias Geológicas, v. 23 , p. 262-276.

Weber, B., Valencia, V.A., Schaaf, P., Pompa-Mera, V., and Ruiz, J., 2008, Significance of provenance ages from the Chiapas Massif complex (southeastern Mexico): Redefining the Paleozoic basement of the Maya block and its evolution in a peri-Gondwanan realm: The Journal of Geology, v. 116, p. 619-639, https://doi.org/10.1086/591994.

Yañez, P., Ruiz, J., Patchett, P.J., Ortega-Gutierrez, F., and Gehrels, G.E., 1991, Isotopic studies of the Acatlan complex, southern Mexico: Implications for Paleozoic North American tectonics: Geological Society of America Bulletin, v. 103, p. 817-828, https://doi.org/10.1130/0016-7606 (1991) $103<0817:$ ISOTAC>2.3.CO;2.

Yang, S., Zhang, F., and Wang, Z., 2012, Grain size distribution and age population of detrital zircons from the Changjiang (Yangtze) River system, China: Chemical Geology, v. 296-297, p. 26-38, https://doi.org/10.1016/j chemgeo.2011.12.016.

Zambito, J.J., IV, and Benison, K.C., 2013, Extremely high temperatures and paleoclimate trends recorded in Permian ephemeral lake halite: Geology, v. 41, p. 587-590, https://doi.org/10.1130/G34078.1.

Zambito, J.J., IV, Benison, C.K., Foster, T.M., Soreghan, G.S., Soreghan, M.J., and Kane, M., 2012, Lithostratigraphy of Permian Red Beds and Evaporites in the Rebecca K. Bounds Core, Greeley County, Kansas: Kansas Geological Survey Open-File Report 2012-15, 45 p.

Zeller, D.E., ed., 1968, The Stratigraphic Succession in Kansas: Kansas Geological Survey Bulletin 189, $81 \mathrm{p}$.

Ziegler, A.M., Scotese, C.R., McKerrow, W.S., Johnson, M.E., and Bambach, R.K., 1979, Paleozoic paleogeography: Annual Review of Earth and Planetary Sciences, v. 7, p. 473-502, https://doi.org/10.1146/annurev.ea 07.050179.002353.

Manuscript Accepted by the Society 7 February 2018

Manuscript Published Online Xx Month 2018 
